\title{
The Reconstruction of Production and Storage Sites for Chemical Warfare Agents and Weapons from Both World Wars in the Context of Assessing Former Munitions Sites
}

\author{
Johannes Preuss
}

\begin{abstract}
This chapter begins by listing the quantities and sites of chemical agent production during both world wars and outlining the relative importance of these new weapons. Using the example of the production sites of World War II, the setting in which the construction and operation of these factories took place will be described, as well as the structure of the facilities. It will be shown that it was not only Fritz Haber's former colleagues who made important contributions to the research of chemical warfare agents and their production, but that an important role was also played by students of his successor at the Kaiser Wilhelm Institute for Physical Chemistry and Electrochemistry. In order to be employed militarily, chemical warfare agents must be put into grenades, bombs, mines, warheads, and spray tanks. This took place at seven filling plants, five of the army and two in air munitions facilities. Gaseous and particularly dangerous modern warfare agents were filled in the chemical factories where they were produced. This article is based on extensive research in the context of the investigation, ongoing since 1979, into former armaments sites, the methodology of which will be briefly outlined. It will be shown that the effects of chemical warfare agents-their production and deployment at the frontline - continue to pose a risk 100 years later. In consideration of general public health, the disposal of these agents of must be prioritized. Also in Germany, these agents have been exploded, burned, and buried, and the residues pose environmental risks. Some of the demolition sites of these agents are still unknown today.
\end{abstract}

\footnotetext{
J. Preuss ( $\square)$

Geographisches Institut, Johannes Gutenberg-Universität Mainz, Mainz, Germany

e-mail: jpreuss@uni-mainz.de

(C) The Author(s) 2017

B. Friedrich et al. (eds.), One Hundred Years of Chemical Warfare: Research,

Deployment, Consequences, DOI 10.1007/978-3-319-51664-6_16
} 


\section{Introduction}

The importance of chemistry and the chemical industry to human well being and prosperity has grown constantly since the mid-nineteenth century. The discoveries of this science are, however, also suited to improving weapons and other armaments employed by states against one another in conflicts.

Whereas the war of 1870-71 was still fought on the German side with around 2,000 metric tons of gunpowder for propellant and explosives (ca. 26 million rounds of infantry munition and ca. 845,000 rounds of artillery munition) (Der deutsch-französische Krieg 1881, 816-19), the situation changed crucially with the development of Granatfüllung 88 (Grf. 88 = picric acid) in 1888 and of Füllpulver 02 (Fp $02=$ trinitrotoluol) in 1902. It was no longer gunpowder factories that were providing propellant and explosives but rather the private chemical industry. Over the course of the First World War, 33 predominantly private factories in Germany produced 510,000 metric tons of explosives and 36 factories 285,000 metric tons of propellant. Seven chemical factories manufactured 47,400 metric tons of chemical warfare agents. In addition, around 450,000 metric tons of intermediate products were required, some of which were taken from limited food supplies for the population (see Table 1).

In Germany during the Second World War, war-related chemical production increased to 977,500 metric tons of explosives (28 factories), 974,000 metric tons of propellant (43 factories), and 69,500 metric tons of chemical warfare agents (10 factories) as well as around 805,000 metric tons of intermediate products (see Table 1 and Table 2 ).

This increase in production was made possible by, among other things, the method Fritz Haber and Carl Bosch developed in the early twentieth century to synthesize ammonia, which was honored with a Nobel Prize and made it unnecessary to import saltpeter from Chile for fertilizer and as a raw material to produce munitions. Over a period of just under seventy-five years the production of explosives and propellants in Germany increased by a factor of 975 .

Even today, the legacies of both world wars have considerable negative significance for the livelihoods of the population, considering that military chemical substances contaminate the soil and ground water in many locations and unexploded munitions pose a threat to public safety.

Table 1 Quantities of propellant and explosives produced for the wars of 1870-71, 1914-18, and 1939-45 (in Metric Tons) (Der deutsch-französische Krieg 1881, 816-19; Preuss and Schneider 2005, 31-47, supplemented)

\begin{tabular}{l|l|l|l|l}
\hline & Explosives & Gunpowder & Chemical agents & Total \\
\hline War of $1870-71$ & - & ca. 2000 & - & 2000 \\
\hline \multirow{2}{*}{ First World War } & 508,198 & 284,808 & 47,395 & 840,401 \\
\cline { 2 - 5 } & 33 factories & 36 factories & 7 factories & 76 factories \\
\hline \multirow{2}{*}{ Second World War } & 977,492 & 974,188 & 69,500 & $2,021,180$ \\
\cline { 2 - 5 } & 28 factories & 43 factories & 10 factories & 81 factories \\
\hline
\end{tabular}




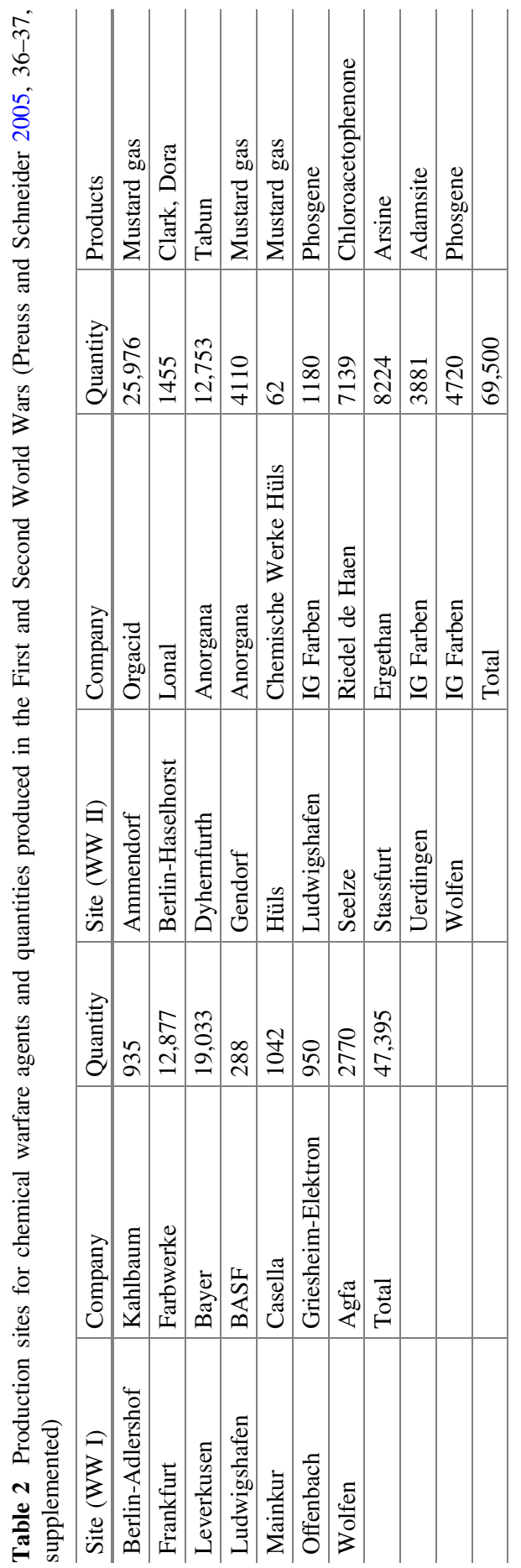


As the cleanup of the former munitions site of Stadtallendorf, near Marburg in the region of Hesse demonstrates, the cleanup of a single munitions waste site can cost taxpayers 160 million euros (Reile 2005, 424).

Since the mid-1980s, former munitions sites in Germany have been tested for waste. The tipping point was September 6, 1979, when an explosion in the basement of a residence in Hamburg caused the death of a child. The explosion was caused by chemicals from the abandoned Chemische Fabrik Dr. Hugo Stoltzenberg. The subsequent investigations revealed that munitions, incendiary materials, and chemical warfare agents were present in large quantities there (Scholz 2004; Brauch and Müller 1985, 331-59). At the time, the Bundesarchiv (Federal Archives) was tasked with researching whether similar events-but especially the occurrence of chemical warfare agents - was also possible in other locations. ${ }^{1}$

The weekly magazine Stern published the results of its own research, which roused the authorities and the citizens. Politicians discovered the topic and funds were made available to study waste sites. In the $1980 \mathrm{~s}$, the munitions waste sites of Hessisch-Lichtenau and Stadtallendorf in Hesse were studied first and a survey was conducted (König and Schneider 1985; Preuss 1990; Preuss et al. 1992a). Even earlier Lower Saxony had begun conducting a survey of munitions waste sites and organized the first conference of experts in the field in 1989.

As part of the environmental research plan of the Bundesminister für Umwelt, Naturschutz und Reaktorsicherheit (Federal Minister for the Environment, Nature Conservation, and Nuclear Safety), research projects were launched to take stock of suspected locations of munitions wastes in Germany. They provided comprehensive lists of sites, studied materials on typical combinations of explosives and chemical warfare agents, and compiled finding aids for federal and state archives (see Thieme 1996). This work provided a practical entry point to the complex theme of "munitions wastes." The Umweltbundesamt (UBA, German Environmental Agency) also supported and assisted exemplary research and study projects in which the guidelines that had been developed could be tested for feasibility. We were able to carry out one such exemplary study (Preuss et al. 2002).

In addition to these UBA programs, handbooks and waste studies were published by the German states (Preuss and Eitelberg 1996) and information gathered on international experience with collecting data, studying, evaluating, and cleaning up the waste of former sites of the armaments industry and the military (Schaefer et al. 1997, 139-44). For federal sites, the process is divided into three phases:

Phase I: Collecting data and initial analysis. This consists of studying the historical development and use of a site and reviewing as applicable the resulting suspicion of waste and describing the site and suspect areas. To that end, the relevant authorities and eyewitnesses are interviewed and promising archives in Germany and abroad visited. In addition to federal archives, state archives,

\footnotetext{
${ }^{1}$ Bundesarchive Koblenz und Freiburg, "Fertigung, Lagerung und Beseitigung chemischer Kampfstoffe unter besonderer Berücksichtigung des Territoriums der Bundesrepublik Deutschland," 1979, Preuss private collection.
} 
municipal archives, local history museums, and residents with an interest in history can be important sources. Not infrequently, the companies that operated former munitions factories have documentation. Maps, building plans, building descriptions, descriptions of production, production figures, and aerial photographs are also evaluated. Although the client does not always want this, it can make sense to visit the site and make an initial assessment of the potential risk to the protected property. Occasionally, this revealed that immediate action was required.

Phase II: Risk assessment. Risk assessment is based on two steps: orientation studies (Phase IIa) and detailed studies (Phase IIb). The goal of Phase IIa is either to disprove the suspicion of the presence of waste through limited site studies or to confirm that suspicion through studies of the presence of hazardous materials, their release and spread, and their effects on the protected property. On former munitions and military sites, the presence of chemical agents is often suspected, so that the sites to be studied first have to be cleared before disturbing the soil. Chemical weapons and hazardous materials also necessitate that a work safety plan be prepared. In addition to suspect areas typical of the site, such as facilities for smelting, mixing, and casting in munitions filling factories or sewage facilities, in many cases a suspicion arises immediately upon entering owing to the presence of munition parts, residues of explosives, and traces of decontaminants or other chemicals. This suspicion can be checked with quick tests or laboratory analysis of soil and material samples. Phase IIa also calls for conducting groundwater studies downstream from potential waste concentrations and, regarding the type of hazardous materials, studies of soil gases. If the initial suspicion is disproven, the area can be removed from the study program. If the initial suspicion is confirmed or the studies are not yet sufficient, in Phase IIb (detailed studies) a program appropriate to the type and extent of the measures based on earlier findings must be worked out. The objective is to contain and assess the contamination in media that can spread it such as soil, groundwater, and soil gases and to assess the risk to the protected property and to make recommendations for further action. If Phase IIb should reveal the necessity for an immediate measure, it must be implemented without delay. If it should reveal the necessity for a safety or cleanup measure (Phase III), additional site studies for these areas may be necessary until it is possible to develop a comprehensive project proposal that addresses all of the questions relevant to a local measure. In practice, moreover, studies that could be conducted in the context of dissertations have also been necessary (see Szöcs 1999; Bausinger 2007; Mense-Stefan 2005).

Figure 1 shows the relevant sites for the production, processing, and storage of chemical warfare agents (see also Tables 2 and 3). In preparation for war, production plants were built and operated in a secret collaboration between the Oberkommando des Heeres (OKH; Supreme High Command of the Army) and companies from the chemical industry. With few exceptions munitions with chemical warfare agents were filled by five munitions plants of the army and two of the air force. Phosgene, which is a gas at room temperature, was filled directly into bombs at the production plants in Wolfen and Ludwigshafen. For safety reasons, the modern nerve gas tabun was filled in bombs and shells in the factory in Dyhernfurth (now Brzeg Dolny), near Breslau (now Wrocław) where it was produced. 


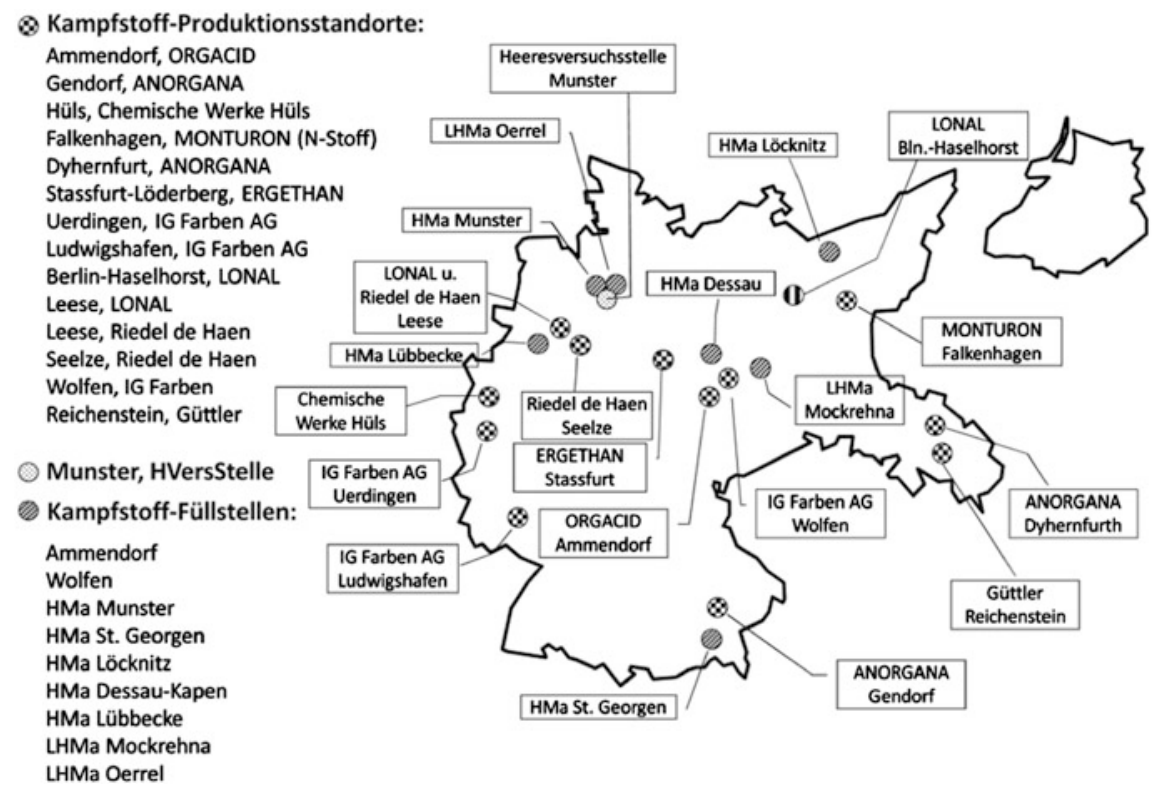

Fig. 1 Working production and filling sites in the Second World War (Kampfstoff-Produktionsstandort (Chemical agents production sites) Munster, HVersStelle [Heeresversuchsstelle] (Munster, army testing site) Kampfstoff-Füllstellen (Chemical munition filling sites))

Table 3 lists 24 production sites for chemical warfare agents, of which just 13 produced a total of 69,500 tons of chemical warfare agents. Five sites were operated directly by private companies; two of them in Ludwigshafen and two in Uerdingen which belonged to IG Farbenindustrie A.G. The necessary intermediate products were already available there. The fifth factory was Riedel de Haen in Seelze, near Hanover.

As part of the collaboration between the $\mathrm{OKH}$ and various companies from the chemical industry, 19 plants were built. The army-owned holding company Montan mediated between the contract partners.

Montan was founded in 1916 as Verwertungsgesellschaft für Montanindustrie $\mathrm{GmbH}$ :

$\S 1$ Messrs. geh[eimer] Kommerzienrat [Privy Commercial Councilor] Ernst Fromm and Dr. Otto Kahn hereby establish a company with limited liability under the name Verwertungsgesellschaft für Montanindustrie, Gesellschaft mit beschränkter Haftung. §2 Company headquarters are in Munich. $\$ 3$ The objective of the company is to acquire mining rights, shares in unions, mining shares, the commercialization of such rights and assets, and participation in similar companies. ${ }^{2}$

\footnotetext{
${ }^{2}$ Justizrat (Legal Councilor) Franz Pündtner, notary in Munich, Articles of association, February 3, 1916, notarized copy, reg. no. 180, Preuss private collection.
} 


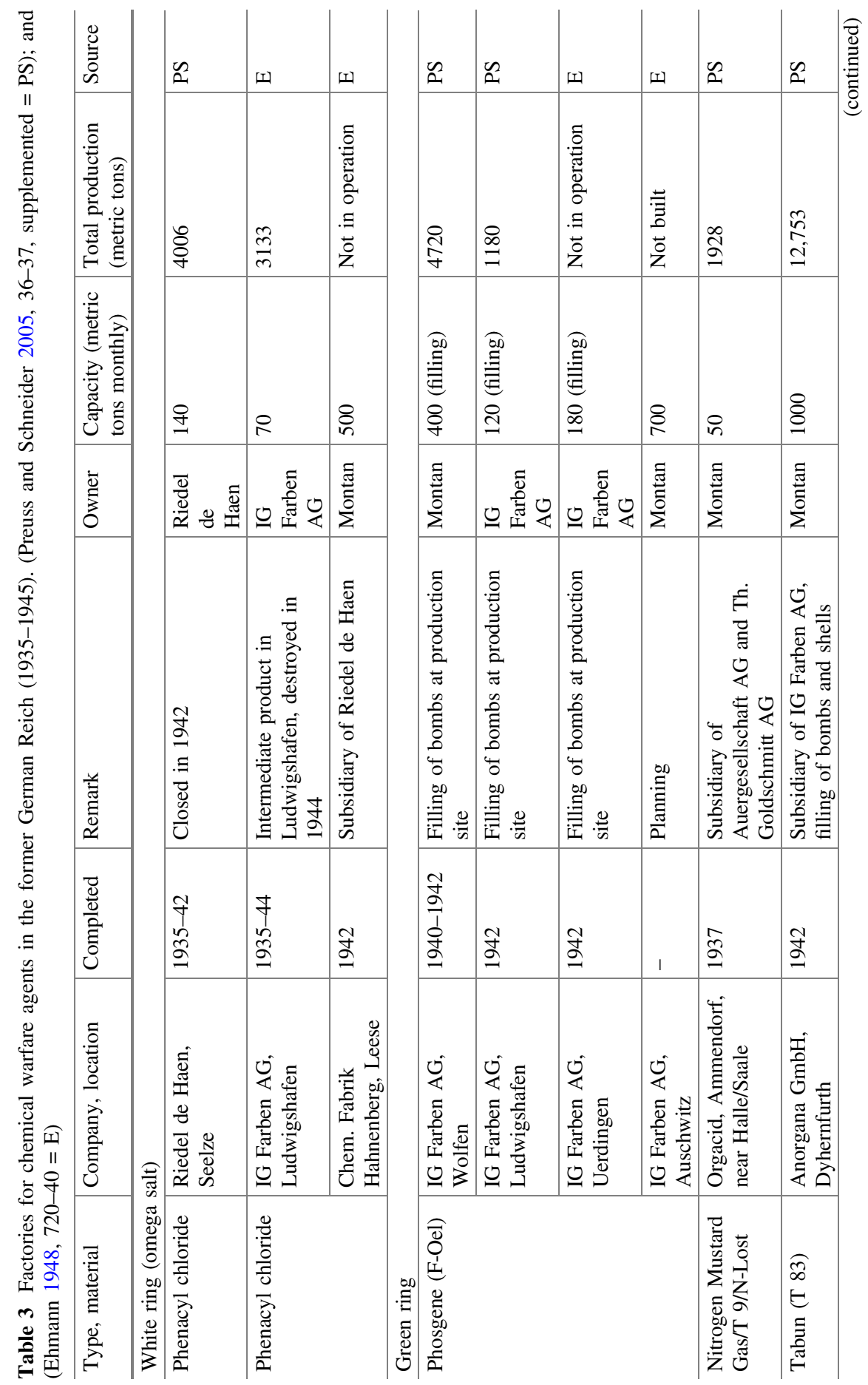




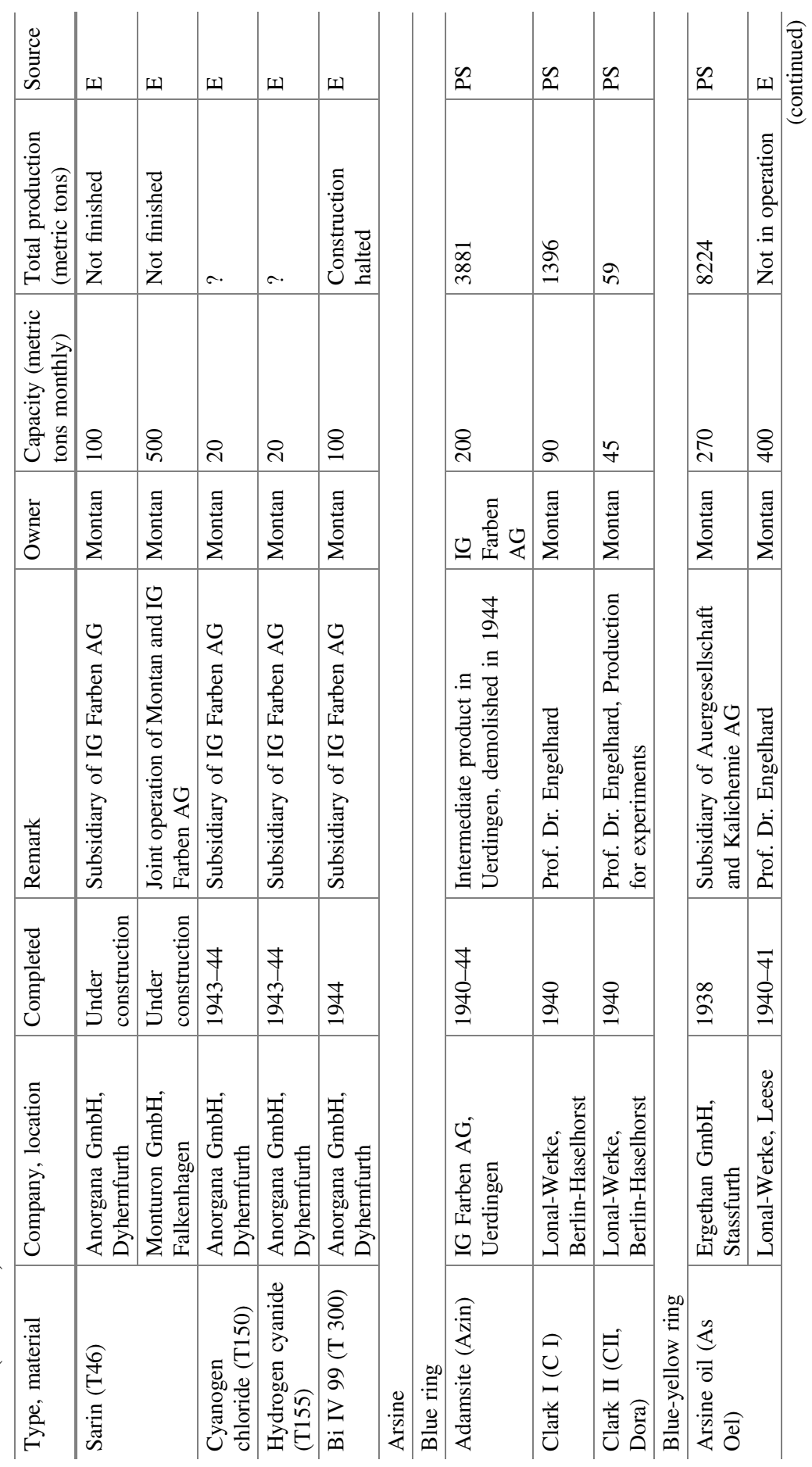




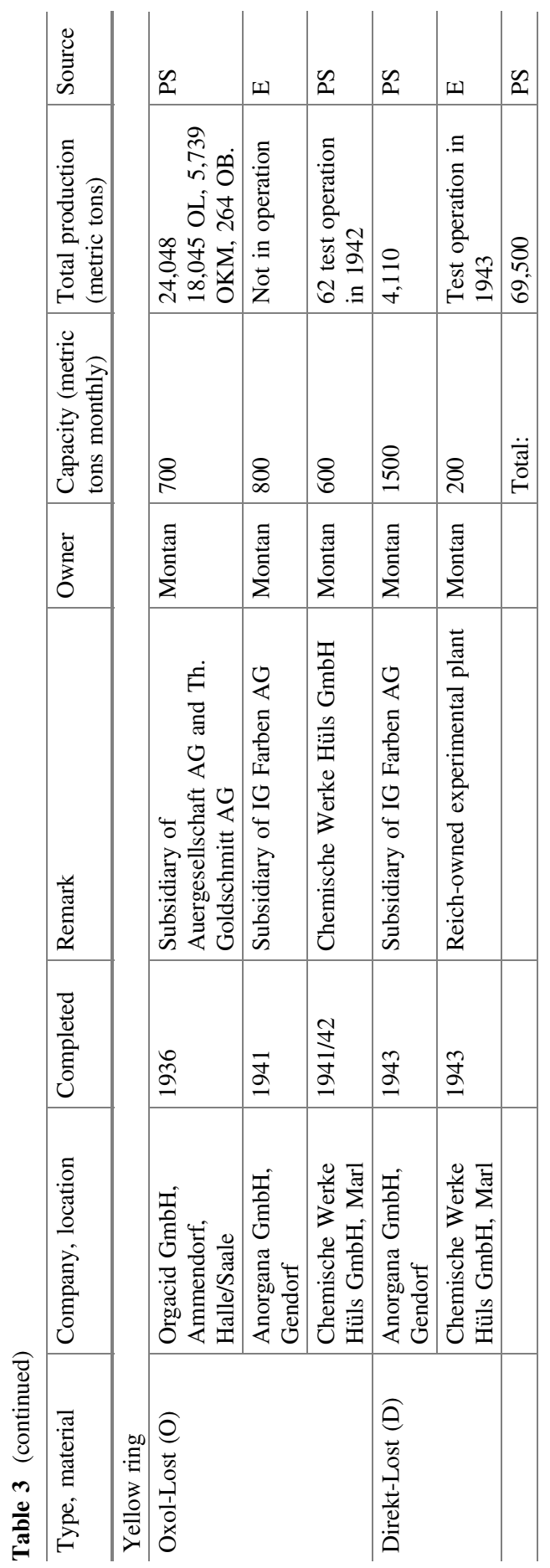


Very soon thereafter it was in the hands of the Eisenwerksgesellschaft Maximilianshütte, Sulzbach-Rosenberg. In 1934 the Geräte- und Apparate Handelsgesellschaft (GERAP) in Berlin acquired ninety-five percent of the shares. That same year the Reich Ministry of War purchased the shelf corporation Montan from GERAP and Maxhütte (Preuss and Schneider 2005, 25-26). The sale had probably been arranged by the former internal corporate auditor of Maxhütte: the businessman Dr. Johann Martin, known as Dr. Max Zeidelhack, ${ }^{3}$ who in early 1934 had transferred to the Heereswaffenamt (HWa; Army Weapons Agency) of the OKH with the rank of Regierungsrat (Senior Civil Servant). Zeidelhack rose to the rank of Ministerialdirigent (Ministerial Director) by 1940. He headed Montan as its first chief executive officer from 1935 to $1942 .{ }^{4}$ During this period, 108 army-owned businesses with 180,000 employees were assembled under Montan's roof, with invested capital of 4.5 billion reichsmarks and a turnover of 1.8 billion reichsmarks in 1942. According to a curriculum vitae in tabular form of 1948, Zeidelhack was born in Bayreuth in 1891. He completed secondary school in Ingolstadt and studied six semesters in Munich (German, History of economics, English, French) before the First World War.

Zeidelhack then served as a lieutenant in the reserve of the Bayerische Schwere Artillerie (Bavarian Heavy Artillery); later he served as first lieutenant, pilot, and fighter pilot. After the war he continued his studies in Munich in the subjects of law and political science, graduating in 1922 and receiving his doctorate. After an apprenticeship in a bank, he worked as an auditor. On January 1, 1934, he began work as a business and contract consultant at the Heereswaffenamt of the Reichswehrministerium (Reich Defense Ministry). From November 1, 1934, he was Oberregierungsrat and head of the department of business administration with responsibility for all the financial contracts with German and foreign industry, in particular for army-owned companies as well as for trust companies and Montan. By his own account, he was dismissed from his Ministerialdirigent post on January 14, 1943, by Reichsminister für Bewaffnung und Munition (Reich Minister for Weapons and Munition) Albert Speer, because he was not prepared to sell the army-owned companies for "a fifth of their share value to friends of the minister in the party." After the war, as part of de-Nazification, Zeidelhack was ranked as a "fellow traveler" (Mitläufer) by Spruchkammer [Sentencing Chamber] VII in Munich and on January 30, 1948, benefited from the Christmas amnesty.

Montan's task was to acquire properties and plants in trust for the $\mathrm{OKH} / \mathrm{HWa}$ and to supervise the construction and operation of factories. In order to camouflage them, the factories appeared on Montan's balance sheets and were thus not immediately recognizable as the property of the Reich. The relationships between

\footnotetext{
${ }^{3}$ Lebenslauf Max Zeidelhack, March 27, 1948, Bayerisches Hauptstaatsarchiv, Munich, Office of Military Government, Bavaria, 13/83-2/5, as well as National Archives, Washington, DC: Microfilm Publication 12065 Sect. 3-402/NNDG no. 775037.

${ }^{4}$ Wehrmacht-Fernsprechverzeichnis [Army Telephone Records] for Greater Berlin, part I, p. 147, February 1, 1943, Dr. Zeidelhack, department head, business administration (Wa Z 3), National Archives, Washington DC., Microfilm T-77, reel 342.
} 
the $\mathrm{OKH}$, Montan, the companies, and the subsidiaries to be founded were regulated by the master or framework agreement and the lease agreement. Under these agreements, the company could produce without capital or risk and profit from the agreements. Shortly before the end of the war, the Reichsminister für Rüstungs- und Kriegsproduktion transferred nearly all of the shares to Montan as free property (Preuss and Schneider 2005, 23-24).

During the postwar period, the factories were demolished and many buildings and plants suitable for armaments were blown up. Refugees were housed in several former factories in West Germany, which led to the founding of the so-called New Cities (e.g., Stadtallendorf, Waldkraiburg, Geretsried, Espelkamp and Traunreut) (Preuss 1990, Preuss et al. 1992a, 1994; Preuss and Eitelberg 2009, 91-115).

In some cases, the occupying troops used the facilities for their own ends. Other munitions plants are even now collections of ruins and rubble in forests that have become shrouded in myths (e.g., Clausthal-Zellerfeld, Reinsdorf, Forst) (Preuss et al. 1993; Bausinger et al. 2005).

Against this backdrop, in what follows we will discuss three factories for the production of chemical warfare agents: the Orgacid GmbH factory in Ammendorf, near Halle an der Saale; the Monturon $\mathrm{GmbH}$ factory in Falkenhagen, near Fürstenwalde; the Anorgana GmbH factory in Dyhernfurth (now Brzeg Dolny) on the Oder River. We will also look at the storage and processing of chemical warfare agents in munitions dumps.

\section{The Ammendorf Factory of Orgacid GmbH}

Just four kilometers from the center of the city of Halle an der Saale, Germany's largest mustard gas factory lies northeast of Ammendorf. The Ammendorf chemical weapons factory of Orgacid $\mathrm{GmbH}$ had a floor area of around twelve hectares. In its final form, it had plants to produce various types of the chemical weapon mustard gas as well as the necessary intermediate products; it also had a plant for filling bombs with chemical warfare agents, which could also be used for shells, and a large storage bunker for $\mathrm{O}$ mustard (oxol mustard) and a smaller one for $\mathrm{N}$ mustard (nitrogen mustard).

Within a radius of a kilometer around the mustard gas bunker, there were railroad tracks and the buildings for the Buckau chemical factory, which produced chlorine gas, among other things, as well as a sports field, the Rosengarten inn, and residential buildings with gardens, which provided the "ideal" camouflage for this important munitions factory. The toxicologically risky sewage of the factory was routed through Ammendorf parallel to an existing trench in a piped section with fourteen shafts, underneath Hallesche Strasse, Hindenburgstrasse, and Hauptstrasse and along Badstrasse to the Elster River. There was also a detour line with an iron pipe sixty centimeters in diameter, which led into the lower trench and also led to the Elster, which reached the Saale River about two and a half kilometers downstream. 
On November 23, 1934, the Degea Aktiengesellschaft (Auergesellschaft), represented by board members Dr. Adolf Gerdes and Dr. Ing. Karl Quasebart, both of Berlin, and the Chemische Fabrik Buckau, represented by its authorized director, Hermann Cordes of Essen, formed a limited liability company called Orgacid $\mathrm{GmbH}$, with headquarters in Berlin. The purpose of the company was the "production and distribution of chemical products of all kinds, especially Orgacid." 5 The chemist Dr. Hermann Engelhard, ${ }^{6}$ also of Berlin, was appointed its chief executive office. The company had an supervisory board of three to five members, on which the OKH/HWa was also represented, by Messrs. Zeidelhack and Zahn. ${ }^{7}$

By a resolution of a special general meeting of December 22, 1937, the assets of the Chemische Fabrik Buckau were transferred to Th. Goldschmitt A.G. in Essen. After recording this change in the commercial register, Chemische Fabrik Buckau was dissolved. The party to the contract was now Th. Goldschmitt AG in Essen. ${ }^{8}$ On December 10, 1934, within three weeks of signing the articles of association, Orgacid's chief executive officer Engelhard received three preliminary notices from the Waffenamt for contracts to build plants to produce polyglycol M, a conversion plant, and a polyglycol $\mathrm{M}$ storage facility in Ammendorf. That meant that the groundwork for the constructing the factory, the ordering of machines, and the setting up of the equipment could begin immediately. ${ }^{9}$

At this time, there was not yet a sales agreement for the property on which the factory was to be constructed. It was not concluded until June 3, 1935. The commercialization company for Montanindustrie $\mathrm{GmbH}$, in Munich, represented by its authorized agent, the businessman Dr. Johann Martin, known as Dr. Max Zeidelhack, from Berlin, then purchased a property in Ammendorf of 75,500 square

\footnotetext{
${ }^{5}$ Gesellschaftsvertrag: Urkunde Nr. 331/1934, Notar Dr. F. Jacke, November 23, 1934, Preuss private collection.

${ }^{6}$ Engelhard was born in Trier, on November 1, 1896. In August 1914, after taking emergency school leaving exams, he became a soldier at seventeen. After the war he began studying chemistry at the Technische Hochschule in Karlsruhe and completed his degree in Munich. Then from 1921 to 1923 he was working at the Kaiser-Wilhelm-Institut für Physikalische Chemie und Elektro-Chemie in Berlin-Dahlem under Fritz Haber. Under the direction of Haber, he received his doctorate at the TH Karlsruhe with a paper on locating gold in seawater. Subsequently, Engelhard worked at the Auer-Gesellschaft AG. By taking over a teaching position on colloid chemistry at the TH Berlin from 1934, he qualified for an honorary professorship. From 1946, Prof. Engelhard was active at the Physiologisch-Chemisches Institut of the Universität Göttingen. See Lebenslauf von Prof. Dr. H. Engelhard, February 15, 1960, Universitätsarchiv Göttingen, UAG-Kur. 10221. Karl Quasebart has also been employed by Fritz Haber. He explored the Atlantic on a research journey of the Meteor as part of the Gold aus Meerwasser (Gold from Seawater) project (Stoltzenberg 1994, 497).

${ }^{7}$ Wehrmacht-Fernsprechverzeichnis [Army Telephone Records] for Greater Berlin, part I, p. 144, June 6, 1943, Dr. Zahn, department head, business administration, head chemist Wa A. National Archives, Washington, DC., Microfilm T-77, reel 342.

${ }^{8}$ Transcription of the copy from the commercial register, Amtsgericht Halle an der Saale, Department B, December 23, 1937, Preuss private collection.

${ }^{9}$ Entwürfe der Schreiben von Wa B 4 VII an die Orgacid GmbH, December 10, 1934, The National Archives, London, FO1031/204.
} 
meters located between the Chemische Fabrik Buckau grounds and the DessauMerseburg train line. The directors of the Buckau factory, Hermann Cordes of Essen and Dr. Camillo Irmscher of Chemische Fabrik Buckau, which still existed at this time, appeared at the signing of the agreement.

On September 20, 1935, the Chemische Fabrik Buckau, Ammendorf; the Degea-Aktiengesellschaft (Auergesellschaft), Berlin; and the German Reich (treasury of the Wehrmacht's department of the army), represented by the Reichskriegsminister (Rkm, Minister of War), signed a legal contract to build a polyglycol factory and a conversion facility. ${ }^{10}$ For purposes of secrecy, the agreement had a passage stipulating that the companies were to be active on behalf of and for the account of the Rkm, but in their own names vis-à-vis outsiders. The plant was to take into account the requirements of air defense, with roof constructions to withstand fire bombing and capable of being blacked out. According to Sect. 2, the land and the existing buildings of Orgacid $\mathrm{GmbH}$ were to be

made available on the basis of a lease agreement still to be concluded by the authorized agent of the Rkm and the commercialization company for Montanindustrie $\mathrm{GmbH}$, Munich, into whose possession all new plants that the companies will operate in trust under section 1 will also be transferred after completion and before beginning operation.

Degea/Auergesellschaft and Chemische Fabrik Buckau were permitted to contract their subsidiary Orgacid $\mathrm{GmbH}$ to build the factory, with which a lease agreement for operating the factory would be signed as well.

The factory grounds were divided into the following sections of production:

- A-Plant for the production of ethylene oxide, ethylene chloride, polyglycol M, and polyglycol MI.

- B-Plant (old) for the production of Oxol mustard gas (O mustard); winter mustard gas (OKM, OB).

- B-Plant (new) for the production of Oxol mustard gas (O mustard); winter mustard gas (OKM, OB).

- T9 plant for the production of nitrogen mustard gas ( $\mathrm{N}$ mustard).

- Plant for filling KC $250 \mathrm{~Gb}$ bombs.

- Sewerage.

The annual report for the fiscal year 1937-38 reveals that production of polyglycol M, ethylene oxide, and ethylene chloride began in May $1937 .^{11}$

\footnotetext{
${ }^{10}$ Vertrag zwischen der Chemischen Fabrik Buckau (Ammendorf), der Degea-Aktiengesellschaft (Auergesellschaft), Berlin, und dem Deutschen Reich (Fiskus des Wehrmachtsteils Heer), vertreten durch den Reichskriegsminister (Rkm) über die Errichtung einer Polyglykolfabrik und einer Umsetzungsanlage, September 20, 1935, Preuss private collection.

${ }^{11}$ Orgacid GmbH, Bericht über das Geschäftsjahr 1937-38, December 21, 1938, Preuss private collection.
} 
Table 4 Construction projects for chemical weapons plants managed by the building department of Orgacid GmbH, later Lonal GmbH (Preuss and Eitelberg 2003b, 65)

\begin{tabular}{l|l|l|l}
\hline $1937-38$ & 1939 & $1940-41$ & $\begin{array}{l}1943-44 \text { (Lonal from } \\
1941-42)\end{array}$ \\
\hline Ammendorf & Ammendorf & Ammendorf & Ammendorf \\
\hline Trostberg & Gendorf & Gendorf & Gendorf \\
\hline Hahnenberg & Hahnenberg & Hahnenberg & Leese \\
\hline- & $\begin{array}{l}\text { Hörpolding (St. } \\
\text { Georgen) }\end{array}$ & $\begin{array}{l}\text { Hörpolding (St. } \\
\text { Georgen) }\end{array}$ & Hörpolding (St. Georgen) \\
\hline Munster & Munster & Munster & Munster \\
\hline- & - & - & Oerrel \\
\hline- & Löcknitz & Löcknitz & Löcknitz \\
\hline- & - & Dessau (Kapen) & Dessau (Kapen) \\
\hline- & - & Lübbecke & Lübbecke \\
\hline- & - & - & Mockrehna \\
\hline
\end{tabular}

In addition, Orgacid $\mathrm{GmbH}$ was granted several construction contracts late in the fiscal year $1937-38$ (see Table 4). ${ }^{12}$

The annual report contains no production figures for the fiscal year 1938-39. The report on the events of the fiscal year reads:

In the new fiscal year the company was contracted to begin producing final products as well. Manufacture began in May [1938] and is slowly increasing. During the critical days of September, the leadership did everything in its power to reach maximum production. Unfortunately, a series of accidents could not be avoided. Now all measures have been taken to reduce such accidents to an absolute minimum. ${ }^{13}$

For the fiscal year 1939-40, the production of various types of mustard gas in B-Plant is documented. ${ }^{14}$ A-Plant continued to produce polyglycol M, polyglycol M I, ethylene oxide, and ethylene chloride.

In A-Plant, which was brought into operation in 1939, production was increased after the war began. In B-Plant, 572 metric tons of Oxol mustard gas were produced per month. In the winter of 1939-40, parts of the plants were closed to make repairs. The experimental plant for nitrogen mustard ( $\mathrm{T}$ 9) was opened without a hitch (Table 5).

Of the 30,148 metric tons of mustard gas produced in the German Reich by the end of the war, 25,976 metric tons $(86.2 \%)$ were from Ammendorf. In the filling plant in Ammendorf, 61,108 bombs (KC $250 \mathrm{~Gb}$ ) were filled with ca. $90.2 \mathrm{~kg}$ for a total of 5512 metric tons of mustard gas.

\footnotetext{
${ }^{12}$ Orgacid GmbH, Bericht über das Geschäftsjahr 1938-39, December 21, 1939, Preuss private collection.

${ }^{13}$ Orgacid GmbH, Bericht über das Geschäftsjahr 1938-39, December 21, 1939, Preuss private collection.

${ }^{14}$ Orgacid GmbH, Bericht über das Geschäftsjahr 1939-40, Preuss private collection.
} 
Table 5 Production of Orgacid GmbH Ammendorf, May 1937-March 1945 (tons, piece)

\begin{tabular}{l|l|l|l|l|l|l|l|l}
\hline Time/Production & $\begin{array}{l}\text { Eth. } \\
\text { ox. }\end{array}$ & PM & PMI & $\begin{array}{l}\text { O } \\
\text { Mustard }\end{array}$ & $\begin{array}{l}\text { OB } \\
\text { Mustard }\end{array}$ & $\begin{array}{l}\text { OKM } \\
\text { Mustard }\end{array}$ & $\begin{array}{l}\text { T 9 } \\
\text { Mustard }\end{array}$ & $\begin{array}{l}\text { KC } \\
250 \mathrm{~Gb}\end{array}$ \\
\hline- & - & - & - & - & - & - & - & - \\
\hline $\begin{array}{l}5 / 1937-3 / 1938 \\
\text { (G) }\end{array}$ & 756 & 2085 & - & - & - & - & - & - \\
\hline $\begin{array}{l}4 / 1938-3 / 1939 \\
\text { (F) }\end{array}$ & 15 & 3507 & - & 2183 & - & - & 19 & - \\
\hline $\begin{array}{l}4 / 1939-3 / 1940 \\
\text { (E) }\end{array}$ & 1872 & 1473 & 3742 & - & 1215 & 118 & - \\
\hline $\begin{array}{l}4 / 1940-3 / 1941 \\
(\mathrm{E})\end{array}$ & 669 & 1828 & 1481 & 3476 & - & 1908 & 293 & 6867 \\
\hline $\begin{array}{l}4 / 1941-3 / 1942 \\
(\mathrm{D})\end{array}$ & 2,206 & 827 & 565 & 3868 & & 789 & 361 & 53,859 \\
\hline $\begin{array}{l}4 / 1942-3 / 1943 \\
\text { (C) }\end{array}$ & 2,115 & 1608 & 396 & 862 & 264 & 399 & 432 & 382 \\
\hline $\begin{array}{l}4 / 1943-3 / 1944 \\
(\mathrm{~B})\end{array}$ & 982 & 2361 & 848 & 2652 & - & 1030 & 516 & - \\
\hline $\begin{array}{l}4 / 1944-12 / 1944 \\
(\mathrm{~A})\end{array}$ & 2,314 & 248 & 128 & 972 & - & 398 & 189 & - \\
\hline $\begin{array}{l}1 / 1945-3 / 1945 \\
(\mathrm{~A} 1)\end{array}$ & $?$ & $?$ & $?$ & 290 & - & - & - & - \\
\hline $5 / 1937-3 / 1945$ & 9,057 & 14,336 & 4891 & 18,045 & 264 & 5739 & 1928 & 61,108 \\
\hline & & & & 25,976 tons of mustard gas & & \\
\hline
\end{tabular}

Key: Eth. ox. ethylene oxide; $P M$ Polyglycol M; $P M I$ Polyglycol M I; $O L$ Oxol mustard gas; $O B$ Winter mustard gas based on S mustard gas/O mustard gas; $O K M$ mustard gas and Dichlordipropylsulfid (mixed/winter mustard gas); $T 9$ nitrogen mustard gas; $K C 250 \mathrm{~Gb}$ chemical bombs filled with $90.2 \mathrm{~kg}$ of mustard gas, of which $47 \%$ were sent to L.H.Ma. Mockrehna, 26\% to L.Ma. Krappitz, 22\% to L.Ma. Domnau, 5\% to L.Ma. Regny, and 7 bombs to Munster. Unfilled chemical warfare agents (O mustard gas, $\mathrm{N}$ mustard gas) were first delivered to Munster and to H.Ma. Löcknitz. The quantities indicated in Table 5 correspond to deliveries to the OKH. For all products, the exception of $\mathrm{KC} 250 \mathrm{~Gb}$, there was additonal production and deliveries to private parties, such as IG Farbenindustrie AG, Frankfurt am Main, and the Lonal-Werk GmbH Berlin. Of the 28,800 metric tons of mustard gas produced in the German Reich by the end of the war, 25,976 metric tons $(=86.2 \%)$ were from Ammendorf. In the filling plant, 61,108 KC $250 \mathrm{~Gb}$ bombs were filled with 5512 metric tons of mustard gas. Table 5 is based on the sources A1-G (Preuss private collection and BArch R 8135/7003 and 7798)

(A1) Boyne, J.G., Lanfear, W.E., Calcott, W.S. and P.J. Leaper (1945): Production of Vesicant Agents at Ammendorf. CIOS,Item No. 8, File No. XXXII-7, p. 8. The British Library, Boston Spa, Wetherby, West Yorkshire

(A) Report der Orgacid GmbH Ammendorf/Saale District, on the fiscal year 1943-44 and on the current fiscal year (additions through December 1944), 4th version, p. 3, January 1945

(B) Report (no. VI/12270) by the Deutsche Revisions- und Treuhand-AG, Berlin on the audit of the annual statement of Orgacid GmbH Ammendorf, near Halle, on March 31, 1944, copy no. 6, p.23

(C) Report (no. VI/11517) by the Deutsche Revisions- und Treuhand-AG, Berlin on the audit of the annual statement of Orgacid GmbH Ammendorf/Saale District, on March 31, 1943, copy no. 6, p. 22

(D) Report (no. VI/10240) by the Deutsche Revisions- und Treuhand-AG, Berlin on the audit of the annual statement of Orgacid GmbH Berlin, on March 31, 1942, copy no. 6, p.21

(E) Report (no. VI/7840) by the Deutsche Revisions- und Treuhand-AG, Berlin on the audit of the annual statement of Orgacid GmbH Berlin, on March 31, 1941, copy no. 11, appendix, p. 28

(F) Report (no. 12795) by the Deutsche Revisions- und Treuhand-AG, Berlin on the audit of the annual statement of Orgacid GmbH Berlin, on March 31, 1939, copy no. 6, p. 6 and appendix, p. 21

( $G$ ) Report (unnumbered) by the Deutsche Revisions- und Treuhand-AG, Berlin on the audit of the annual statement of Orgacid GmbH Berlin, on March 31, 1938, copy no. 7, appendix, p.21 
In the fiscal year 1940-41, production of chemical warfare agents continued. Production of Oxol mustard gas and winter mustard gas could not be continued at full capacity because of a shortage of storage space, so it was halted in the months of August and November. ${ }^{15}$ Production of T 9 (nitrogen mustard gas) was slowed by inadequate supply of intermediate products. The expansion of the factory was continued.

During the fiscal year 1941-42, Orgacid was split into two divisions. From June 1941, there was Orgacid $\mathrm{GmbH}$, building department, Berlin, and Orgacid $\mathrm{GmbH}$, operations, Ammendorf. The building department was transferred to Lonal-Werke $\mathrm{GmbH}$, Berlin, in October 1941. ${ }^{16}$

Production of mustard gas (OL and OKM) in B-Plant averaged 476 metric tons per month. A shortage of workers caused considerable difficulties. B-Plant had to be closed for three weeks beginning in mid-December 1941 because of health problems among the workers. During the fiscal year 1942-43, A-Plant achieved its highest ever production numbers for ethylene oxide. But production of polygycol $\mathrm{M}$ or polygycol M I continued for only five months, so that only 1,608 metric tons could be produced. This led to a considerable decline in production in B-Plant. For that reason, almost no Oxol mustard gas at all was produced in the fiscal year 1942-43. There were 399 metric tons of OKM produced. In addition, preparations for the production of $\mathrm{OB}$ were affected, and 230 metric tons were produced as part of an experimental production.

In T 9-Plant, its production capacity of 50 metric tons monthly could not be exploited fully because of reduced supplies of intermediate products.

The filling plant was closed for the entire year, apart from April 1942, because of a lack of orders. In April, 382 bombs were filled.

The expansion of the factory continued in 1943-44. In order to increase production of OB, B-Plant was further expanded. The storeroom of T-9-Plant was enlarged by installing a fourth vat of 120 metric tons. ${ }^{17}$

On April 18 and 19, 1945, Ammendorf was occupied by American troops and guarded by about thirty American soldiers until it could be cleared out later. At this time, stores consisted of 600 metric tons of arsenic powder from Leese and 625 metric tons of mustard gas. When American troops arrived, numerous files and documents were confiscated. ${ }^{18}$ That may have been connected with the visit by a CIOS team, which presented an extensive report including plans and process diagrams. ${ }^{19}$

\footnotetext{
${ }^{15}$ Orgacid GmbH, Vorläufiger Geschäftsbericht über das Geschäftsjahr 1940-41, from April 1, 1941 to December 31, 1940, p. 1, Preuss private collection.

${ }^{16}$ Orgacid $\mathrm{GmbH}$, Vorläufiger Geschäftsbericht über das Geschäftsjahr 1941-42, from April 1, 1941 to December 31 1941, p. 1, Preuss private collection.

${ }^{17}$ Orgacid GmbH, Bericht über das Geschäftsjahr 1943-44, p. 3, Preuss private collection.

${ }^{18}$ Sekretariat K, Essen, Bericht: Betrifft: Orgacid GmbH Essen, May 28, 1945, Preuss private collection.

${ }^{19}$ Boyne et al. 1945. Production of Vesicant Agents at Ammendorf. M52.D92., CIOS Target No. 8/30 Chemical Warfare, Item No. 8, File No XXXII-7, Combined Intelligence Objectives
} 
It is not known what happened on the grounds during the course of dismantling by the Soviet Military Administration in Germany (Sovyetskaya Voyennaya Administratsya v Germanii, SVAG). The first studies and simple cleanups were carried out in the 1950 s. $^{20}$ A study by Chemiewerk Kapen, near Dessau, in 1953 produced the following results: Some of several bunkers and underground cisterns were still well preserved, while others had been blown up. A lead-lined iron container with a capacity of 2-3 cubic meters in one part of the facility was found to be contaminated with chemical warfare agents. The former grounds of the filling plant smelled of chemical agents; empty bombs and artillery shells were lying around. The remains of the structure of the filling plant were recognizable. The storage bunker for mustard gas had eight cells. They contained

ca. 1,400 cubic meters of water with small amounts of mustard gas, including ca. 150 cubic meters of concentrated nitrogen mustard, which forms a layer of insulation from the water above by means of hydrolysis. ${ }^{21}$

Later "ca. 110 metric tons of sulfur mustard were found in the reinforced-steel bunkers," of which 52.5 cubic meters mustard gas were destroyed in Kapen, and 855 cubic meters of neutralized liquids were directed into the Elster. Nearly two years later, tests of the mustard sludge in the cells of the mustard gas storage bunker still had high levels of mustard gas. Substances active in mustard gas represented as much as $50 \%$; thiodigycol, sulfone, and sulfoxide were also found. The water above the sludge had a $\mathrm{pH}$ of 1.0.

The final report on measures and determinations from 1956 reads as follows:

\begin{abstract}
Work was begun on April 16, 1956, and conducted according to the instructions of May 11, 1956. All of the containers and trenches were examined for chemical warfare agents, then decontaminated and filled with gravel. The mustard sludge located in the bunker cells was destroyed by us at the site. [...] After emptying the cells, the floors and walls were decontaminated and cleaned. The cell openings were then walled up. It was therefore unnecessary to fill the cells, since the cells are empty and decontaminated. Around 4,000 cubic meters of gravel were moved to fill communication trenches, funnels and pits. Work was completed on December 21, $1956 .^{22}$
\end{abstract}

It also reported that 75 cubic meters of mustard sludge were neutralized and destroyed between April 1956 and April 1957; 15 cubic meters of mustard sludge were said to have been found in each of the seven bunker cells. Around $50 \%$ of the

\title{
(Footnote 19 continued)
}

Sub-Committee G-2 Division, SHAEF (Rear) APO 413, National Archives, Washington, RG 338 and British Library, Document Supply Center, Boston Spa.

${ }^{20}$ The discussions referred to in what follows are based on Arbeitsberichte Chemie Werk Kapen, p. 1247 (April 17, 1957), p. 1249 (February 11, 1957), p. 1722 (February 2, 1957) sowie Zusammenfassungen von Berichten zwischen dem January 29, 1953, to July 23, 1956, Preuss private collection.

${ }^{21}$ Ibid.

${ }^{22}$ Arbeitsberichte Chemie Werk Kapen, p. 1247 (April 17, 1957), p. 1249 (February 11, 1957), p. 1722 (February 2, 1957), sowie Zusammenfassungen von Berichten zwischen dem January 29, 1953, to July 23, 1956, Preuss private collection. 
factory grounds (southern part) were decontaminated; that area was said to be usable under certain conditions. The plan was to close the northern part for fifty years. The situation did not change in the 1960s. According to notes on proposals concerning the problems of the Orgacid buildings made to an advisory committee of the District of Halle on June $6,1978,{ }^{23}$ the division of the grounds was still recommended, with the northern part to be closed for fifty years (with entry prohibited), but with the involvement of the chemical weapons expert Professor Karlheinz Lohs it was to be further divided into the "bunker area" and the "remainder of the northern part." Permission was granted to add soil to a height of at least three meters, on which it was said to be possible to build without a foundation. The conditions in the southern part were unchanged. The area around the factory up to a distance of 50 meters were included in these measures. ${ }^{23}$ In February 1990, members of the officers' college of the ground forces of the Nationale Volksarmee (NVA; National People's Army) in Löbau-Zittau visited the city of Halle. ${ }^{24}$ The subject of the visit was "guaranteeing order and safety on the former site of Orgacid, Halle-Ammendorf." One of them was the chemical weapons expert Colonel Professor Siegfried Franke, who had already been involved in the decontamination efforts of the Chemie-Werk Kapen. He explained that chemical warfare agents had still been present only in the mustard gas bunker, but they had been completely removed. At the time, sulfur mustard had been found but not nitrogen mustard or arsenic. Based on this assessment of the situation, it seemed necessary to the participants of the event to "rethink earlier arrangements.", 25

Additional site studies have been conducted since 1990 (Fig. 2, Table 6).

\section{The History of Falkenhagen Factory of Monturon GmbH, Development, the Structure of the Buildings, and Production}

The following text is based on an assessment of the Falkenhagen factory of Monturon $\mathrm{GmbH}$ as part of an investigation of this former munition site (Preuss and Eitelberg 1994).

The area of around nine square kilometers where the former factory grounds of the "Seewerk" Falkenhagen (Falkenhagen "Lake Factory") of Monturon GmbH are located is around $40 \mathrm{~km}$ east of Berlin and $10 \mathrm{~km}$ west of Frankfurt an der Oder, in the forested area of the Falkenhagener Heide (Falkenhagen Heath) between Falkenhagen to the west, Döbberin to the northeast, and Petershagen to the south.

\footnotetext{
${ }^{23}$ Niederschrift zur Beratung über die Problematik Orgacid-Gebäude, June 6, 1978, District Council of Halle, Preuss private collection.

${ }^{24}$ Aktennotiz zum Besuch der Offiziershochschule Löbau-Zittau der Landstreitkräfte der NVA, February 21, 1990, Preuss private collection.

${ }^{25}$ Ibid.
} 


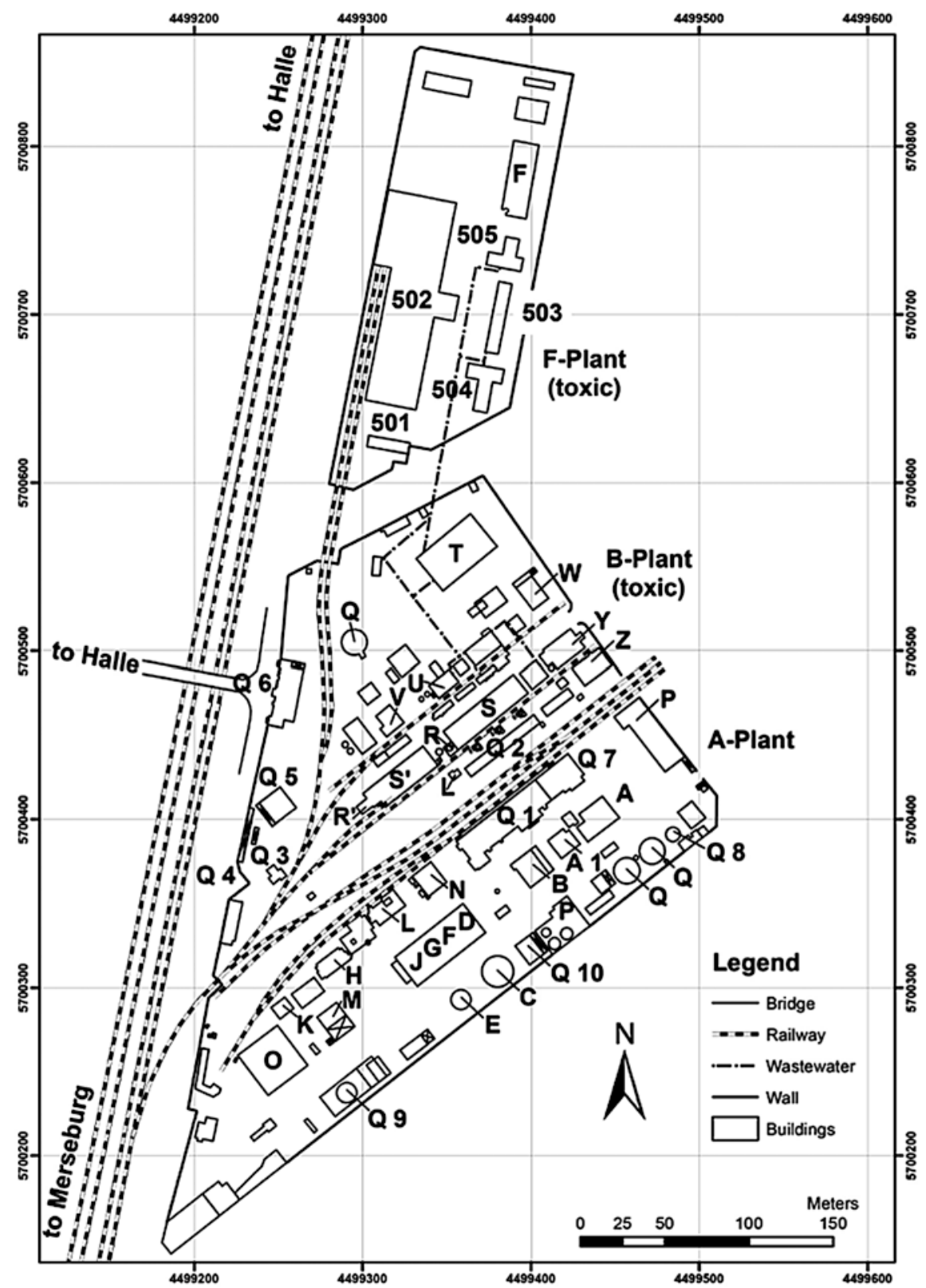

Fig. 2 Layout of Orgacid GmbH Ammendorf (Werkspläne von 1922-1928; Old building fabric, factory plan, A-Plant, 1935, Preuss private collection; Factory plan of 1940, scale 1:500: F-Plant (filling plant); Factory plan of May 1940, revised by VEB Chem. Werke Buna, Schkoppau, 1977; Factory plan of autumn 1942, scale 1:500: Reichsbahnanschluss Orgacid GmbH Ammendorf, Preuss private collection. Boyne, J.G., E.W. Lanfear, W.S. Calcott and P.J. Leaper. 1945. Production of Vesicant Agents at Ammendorf. M52.D92., CIOS Target No. 8/30 Chemical Warfare, Item No.8, File No. XXXII-7, Combined Intelligence Objektives Sub-Committee G-2 Division, SHAEF (Rear) APO 413, National Archives, Washington DC., RG 338 and British Library, Document Supply Center, Boston Spa, Weatherby, West Yorkshire) 
Table 6 Inventory of buildings: Orgacid $\mathrm{GmbH}$ Ammendorf

\begin{tabular}{|c|c|c|}
\hline Plant & Building No. & Function \\
\hline \multirow[t]{29}{*}{ A-plant } & $\mathrm{A} / \mathrm{II}$ & Alcohol rectification and storage \\
\hline & $\mathrm{A} 1 / \mathrm{II}$ & Alcohol storage \\
\hline & $\mathrm{B} / \mathrm{I}$ & Ethylene furnaces \\
\hline & C/XIV & Ethylene storage \\
\hline & D/XIX & Ethylene purification \\
\hline & $\mathrm{E} / \mathrm{XV}$ & Ethylene storage (pure), $1000 \mathrm{~m}^{3}$ \\
\hline & F/XIX & Chlorhydrine manufacture \\
\hline & G/XIX & Ethylene oxide manufacture \\
\hline & H/XVIII & Ethylene oxide storage \\
\hline & J/XIX & Thiodiglycol manufacture \\
\hline & $\mathrm{K} /-$ & Sulfur storage \\
\hline & L/XVII & Chlorine storage \\
\hline & M/- & Hydrogen sulfide manufacture \\
\hline & N/XVI & Lime slaking and solution \\
\hline & $\mathrm{O} / \mathrm{X}$ & Neutralization, waste treatment \\
\hline & P/II, VII, VIII & Thiodiglycol storage \\
\hline & $\mathrm{P} /-$ & Thiodiglycol storage \\
\hline & $\mathrm{Q} / \mathrm{XI}$ & Hydrogen storage \\
\hline & $\mathrm{Q} / \mathrm{XII}$ & Storage, $3000 \mathrm{~m}^{3}$ \\
\hline & Q1/- & Washrooms and changing rooms, decontamination \\
\hline & Q2/- & First aid \\
\hline & Q3/- & Guard room \\
\hline & Q4/- & Main gate \\
\hline & Q5/- & Stores \\
\hline & Q6/- & Administration offices \\
\hline & Q7/IX & Workshop, warehouse \\
\hline & Q8/XIII & Storage, $200 \mathrm{~m}^{3}$ \\
\hline & Q9/XXI & Cooling tower \\
\hline & Q10/XXIII & Warehouse \\
\hline \multirow[t]{11}{*}{ B-plant } & $\mathrm{R} /-$ & Hydrogen chloride burners \\
\hline & $\mathrm{R}^{\prime} /-$ & Hydrogen chloride burners \\
\hline & S/- & Mustard gas reactor \\
\hline & $\mathrm{S}^{\prime} /-$ & Mustard gas reactor \\
\hline & $\mathrm{T} /-$ & Mustard gas storage \\
\hline & $\mathrm{U}$ & Decontamination of toxic wastes \\
\hline & V & Nontoxic wastes \\
\hline & W/- & Triethanolamin-thionylchloride reactors(T-9) \\
\hline & $\mathrm{X} /-$ & Soda storage and solution \\
\hline & Y/- & T-9 neutralization, etc. \\
\hline & $\mathrm{Z} /-$ & T-9 storage \\
\hline
\end{tabular}


Table 6 (continued)

\begin{tabular}{l|l|l}
\hline Plant & Building No. & Function \\
\hline \multirow{2}{*}{ F-plant } & 501 & Administration office \\
\cline { 2 - 3 } & 502 & Large aboveground workshop with charging machines \\
\cline { 2 - 3 } & 503 & Common rooms with kitchen \\
\cline { 2 - 3 } & 504 & Washrooms and changing rooms, nontoxic \\
\cline { 2 - 3 } & 505 & Washrooms and changing rooms, toxic \\
\cline { 2 - 3 } & F & Static water tank \\
\hline
\end{tabular}

Werkspläne von 1922-1928, Gebäudealtbestand, Werksplan A-Anlage, 1935; Werksplan von 1940, scale 1:500: F-Plant (filling plant); Werksplan vom May 1940, revised by VEB Chem. Werke Buna, Schkoppau, 1977; Werksplan vom Herbst 1942, scale 1:500: Reichsbahnanschluss Orgacid GmbH Ammendorf, Preuss private collection; Boyne, J.G., E.W. Lanfear, W.S. Calcott and P.J. Leaper. 1945. Production of Vesicant Agents at Ammendorf. M52.D92., CIOS Target No. 8/30 Chemical Warfare, Item No. 8, File No. XXXII-7, Combined Intelligence Objektives Sub-Committee G-2 Division, SHAEF (Rear) APO 413, National Archives, Washington, RG 338 and British Library, Document Supply Center, Boston Spa, Wetherby, West Yorkshire

In the Falkenhagener Heide in November 1938, groundwork was begun for the building of an industrial site to produce the incendiary material chlorine trifluoride $\left(\mathrm{ClF}_{3}\right)$ (code name N-Stoff [Substance N]). According to a decision in May 1942, another large facility for sarin production was to be built in the same location. ${ }^{26}$ This construction project was set to begin in September 1943. In contrast to the cramped site of the Orgacid factory in Ammendorf, the grounds on the Falkenhagener Heide were oversized. The history of the factory's development and its background were presented in detail by Schmaltz (2005) under the motto "Wunderwaffe N-Stoff" (N Substance: The Miracle Weapon). It was crucial that Hitler was fascinated by this particular incendiary material and had great hopes for it. On the other hand, there must have been a group of interested parties behind the project that made it possible for more than 60 million reichsmarks to have been spent already by the end of March 1944 without any N-Stoff being produced. At the same time, the competition between the research department of the Heereswaffenamt and the laboratories of IG Farbenindustrie AG also played a role, as did competition with the increasingly powerful SS later.

The Forschungsabteilung des Waffenamtes (WaF; Research Department of the Weapons Agency) was engaged in November 1938 to immediately begin groundwork for a new facility in Falkenhagen (Muna-Ost [Muna East] or M.O.) (Schmaltz 2005, 152). Owing to the project's urgency, the acquisition of the site and the construction were to be handled by Montan or carried out under its control. $^{27}$

\footnotetext{
${ }^{26}$ Klenck, Jürgen E. von "History of the 'Seewerk' (Falkenhagen)” 26. March 1945, p. 1/69. The National Archives, London, WO 208/2186.

${ }^{27}$ Schreiben der Waffenamt-Forschungsabteilung (WaF) an den Chef Wa J Rü betreffend Muna-Ost, December 1938, Preuss private collection.
} 
From mid-May 1943, there were plans to produce the new chemical weapon sarin in a large facility (500 metric tons monthly) in Falkenhagen (Schmaltz 2005, 159). That decision was preceded by an order to transfer Falkenhagen to IG Farben by February 12, 1943. The head of the agency, General Leeb, wanted Professor Thiessen of the Kaiser Wilhelm Institute to participate in a preliminary discussion on this. $^{28}$ The construction and management of this large facility exceeded the capabilities of the Waffenamt's research department, so the Falkenhagen construction site was transferred to IG Farbenindustrie AG or more precisely to its Turon GmbH subsidiary on September 1, 1943, after the transfer of the Falkenhagen construction site had been discussed at the site itself on July 23, 1943. ${ }^{29}$ Turon was still in the process of being founded at this time. The legal form was the lease agreement of September 1, 1943, which concerned the factory and all its associated facilities. Only the forest and the management thereof remained in the hands of Montan. ${ }^{30}$ On September 3, 1943, Turon GmbH was founded, with headquarters in Ludwigshafen. The share capital of the company was split equally between Montan Industriewerke $\mathrm{GmbH}$ and IG Farbenindustrie AG. Turon was later renamed Monturon to avoid a confusion of names. ${ }^{31}$ The chief executive officer of Monturon was Director Dr. Otto Ambros; his representative was Dr. Jürgen E. von Klenck; von Klenck, chief engineer Bilfinger, and Röhr (MBA) were named as internal auditors. ${ }^{32}$

The significance of the new product sarin is clear from a report on the production of chemical warfare agents of February $1,1944 .{ }^{33}$ In addition to the experimental facility in Heidkrug, near Munster (capacity 40 metric tons monthly), two expansion stages were constructed at this time following different procedures. These were the experimental facility Sarin I in Dyhernfurth with 100 metric tons monthly and

\footnotetext{
${ }^{28}$ Chef des Stabes (Scholz) an WaF, Betr.: Sondervorhaben Falkenhagen, February 2, 1943, Preuss private collection.

${ }^{29}$ Aktenotiz des Wa J Rü (Mun) - Az. 70 o 40-19 Wa J Rü/Mun 3 zbV/IX; Nr. 1320/43 g.Kdos. betreffend die Ausweichstelle des Reichsamtes für Wirtschaftsausbau in Falkenhagen, July 26, 1943, Preuss private collection.

${ }^{30}$ Schreiben von Oberst a.D. Hammer, Falkenhagen an die Verwertungsgesellschaft für Montanindustrie GmbH, München, September 18, 1943, Preuss private collection.

${ }^{31}$ Monturon GmbH. Abschlussbericht, 1943-44, Fabrikhauptbuch Seewerk, Preuss private collection, and Schmaltz 2005, 160 n. 520.

${ }^{32}$ Dr. von Klenck was born in Bromberg on June 8, 1909. He attended school in Frankfurt am Main, Frankfurt an der Oder, Berlin, and Cologne. After graduating secondary school, he studied chemistry in Cologne and Göttingen. In December 1933 he passed his doctoral exams under Professor Thiessen. His first position was at IG Farbenindustrie A.G. in Höchst. From 1935 to 1940 he was a member of the Allgemeine SS in Frankfurt. He claimed to have been a lieutenant with the 29th flak regiment (Frankfurt) from the time the war broke out. In February 1942 he was conscripted to work at IG Farbenindustrie in Ludwigshafen and was appointed vice deputy director of Monturon in Falkenhagen (Seewerk). He experienced the end of the war in the Anorgana factory in Gendorf, where he was arrested on May 20, 1945, because of his previous membership in the SS and transferred to Dustbin, Enemy Personnel Exploitation Section, FIAT, Control Commission for Germany (BE), B.A.O.R. In FIAT EP 254-84 (von Klenck), December 14, 1945, Interrogation Report, p. 5. The National Archives, London, FO 1031/97.

33،"Deutsche Kampfstoff-Produktion, Ludwigshafen am Rhein," February 1, 1944, BArch R3/1894, p. 6.
} 
the large facility Sarin II in Falkenhagen with 500 metric tons monthly. The large facility in Falkenhagen had a planned budget of ca. 44 million reichsmarks, ${ }^{34}$ of which 380,000 reichsmarks had been spent by January 1944. The planned start date was "mid-1945." These anticipated costs for the sarin plant contrast starkly with the cost value of the Falkenhagen N-Stoff factory reported on March 31,1944. ${ }^{35}$ At that time it was more than 61 million reichsmarks. This recalls the mismanagement in the production of infantry munitions, whose production in 1939-40 was reduced in the middle of the war at one third (Preuss and Eitelberg 2010, 185-89).

The involvement of IG Farbenindustrie AG is also evident in the draft agreement of June 13, 1944, between the German Reich (office of the army), the Verwertungs gesellschaft für Montanindustrie $\mathrm{GmbH}$, IG Farbenindustrie AG, and Monturon $\mathrm{GmbH}$ concerning the expansion of the N-Stoff plant of the $\mathrm{OKH}$ by adding a fabrication facility to produce 500 metric tons monthly of sarin. ${ }^{36}$ According to that contract, IG Farben was also supposed to determine how the N-Stoff plant with provisional capacity of 10 to 15 metric tons monthly could be put into operation.

Precisely a year after the deadline for preparations to transfer the Falkenhagen factory to Monturon, matters took an astonishing turn. On July 23, 1944, the building inspector Glupe (Wa F), who was responsible for the opening of the N-Stoff plant, arrived in the company of SS officers and handed Monturon's management a letter from the brigade leader Dr. Otto Schwab (head of the technical office in the main office of the SS leadership) (SS-Führungs-Hauptamt) that read as follows:

With reference to the order, known to you, from the Führer and head of OKH 1731/44 of July 7, 1944, you are hereby informed that the Führer also ordered that the N-Stoff factory be taken over immediately by the Waffen SS. The agreements between the Heeres-Waffenamt and IG Farben are to be annulled effective immediately and measures already undertaken reversed. [...] Its seamless transfer [...] is the responsibility of the current head of the factory, Dr. Glupe. ${ }^{37}$

The expansion was to be continued; the production of N-Stoff was to begin in August $1944 .{ }^{38}$ The new owners, the Waffen-SS, wanted the N-Stoff facility to be under the direction of Dr. Siegfried Glupe, a former employee of the

\footnotetext{
${ }^{34}$ Entwurf eines Bau- und Errichtungsauftrages für die Errichtung der Sarin II Anlage in Seewerk (Auftrags-Nr. 3/IX-4888-9026/43). The National Archives, London, FO 1031/179.

${ }^{35}$ MONTURON GmbH, Aufstellung des Buchwertes zum 31.03.1944 (= Anschaffungswert 1944), Werk Falkenhagen, Preuss private collection.

${ }^{36}$ Draft agreement: Vertrag zwischen dem Deutschen Reich (Wehrmachtsfiskus), vertreten durch das Oberkommando des Heeres (OKH), der Verwertungsgesellschaft für Montanindustrie GmbH, der IG Farbenindustrie AG und der Monturon GmbH über die Erweiterung der $\mathrm{OKH}$-eigenen N-Stoff-Anlage durch eine Fabrikationsstätte zur Herstellung von 500 moto Sarin, June 3, 1944, Preuss private collection.

${ }^{37}$ Monturon to the Verwertungsgesellschaft für Montanindustrie, August 2, 1944, concerning the demand by the SS that the factory in Falkenhagen be transferred, July 23, 1944, Preuss private collection. The letter is from Director Ambros and signed by his representative, v. Klenck. On this, see also Schmaltz $(2005,171)$.

${ }^{38}$ Aktenvermerk der Montan betreffend Seewerk, July 25, 1944, Preuss private collection.
} 
Kaiser-Wilhelm-Institut für physikalische Chemie und Elektrochemie, whose doctoral advisor had been Prof. Thiessen (Schmaltz 2005, 146). At this time Glupe was section head of the research department of the Heeres-Waffenamt (Wa F, Gruppe IIc) His group leader was Prof. Eschenbach. ${ }^{39}$ Glupe guaranteed that ten metric tons would be produced in September. Experimental production seems to have begun in October 1944; a production report from December 1944 mentions a quantity of 5 metric tons produced $^{40}$; according to von Klenck, a total of 22 metric tons were produced. ${ }^{41}$

The end of the Falkenhagen factory is documented by a letter from Monturon $\mathrm{GmbH}$, informing Montan in February 1945 that the N-Plant of the factory had been closed when the Oderbruch became part of the battle zone. ${ }^{42}$ It can be assumed that the factory was occupied by Soviet troops by April 19, 1945, at the latest (Griess 1985, 82).

At the instructions of $\mathrm{OKH}$ and in agreement with the technical office in the headquarters of the SS, already on February 10, 1945, sixty freight cars with special equipment and machines and five empty tank cars departed for Stulln, Bavaria. After the war Glupe reported that in February 1945 a total of five trains were prepared with goods to be relocated to Stulln, but only four arrived there, and one remained behind in Prague. Other material, he claimed, had been transported to Leese including things from the Anorgana factory in Dyhernfurth. ${ }^{43}$ According to a letter from the Luranil-Baugesellschaft $\mathrm{mbH}$, material was also transported from the Falkenhagen construction to the Gendorf factory of $\mathrm{GmbH} .{ }^{44}$ The company assets belonging to the "Seewerk" Falkenhagen were first seized and later expropriated by the Soviet Military Administration in Germany. ${ }^{45}$

\section{Production at the Falkenhagen Factory}

Originally, the factory in Falkenhagen was only supposed to produce the incendiary material chlorine trifluoride (N-Stoff). The plan was to have an experimental facility with a monthly capacity of 10 metric tons, which would be increased to 50 metric tons.

\footnotetext{
${ }^{39}$ Abschrift/Bu. des Fernsprechverzeichnisses des $\mathrm{H}$ Wa, Forschungsabteilung (mit Hochschulzentralstelle), z. Zt. Kummersdorf-Schiessplatz, Preuss private collection.

${ }^{40}$ Fertigungsbericht C-Stoff, Fertigung in December 1944, p. 87, BArch R 3/1894.

${ }^{41}$ Klenck, Jürgen E. von, "History of the 'Seewerk' (Falkenhagen)," March 26, 1945, p. 3/71, The National Archives, London, WO 208/2186. The author, von Klenck, was the vice deputy director of Monturon GmbH.

${ }^{42}$ Rundschreiben der Monturon GmbH, Nr. 914/45/IVa1/Pr. an die Montan-Industriewerke GmbH betreffend Betriebsstillegungen und Verlagerungen, February 1945, Preuss private collection.

${ }^{43}$ Aktenvermerk (Nr. 8) der IVG betreffend nach Stulln verlagertes Gut aus Falkenhagen, May 23, 1952, Preuss private collection.

${ }^{44}$ Schreiben der Luranil-Baugesellschaft mbH (in Auflösung) an das IG Farben Control Office (Liquidation section), Frankfurt am Main betreffend Silbermaterial, Frankfurt am Main, January 18, 1951, Preuss private collection.

${ }^{45}$ Verfügung der Landesregierung Brandenburg, Enteignungsurkunde für das beschlagnahmte Betriebsvermögen der Firma M.O. Falkenberg (!), Falkenberg, Kreis Lebus, July 7, 1848, Preuss private collection.
} 
The deadline to begin operations was October 1944 and the total quantity produced 22 metric tons was stated, probably accurately, by the vice deputy director of Monturon, von Klenck. ${ }^{46}$

In May 1943, it was also decided to move the planned large production 500 metric tons monthly of the nerve gas sarin to Falkenhagen as well. Construction for that facility began in September $1943^{47}$; completion was planned for April or Mai $1945 .{ }^{48}$ In early February 1945, the Falkenhagen factory was cleared out, because the front was moving closer, so the sarin facility was neither completed nor put into operation.

\subsection{Brief Description of the Facilities at the Factory}

The area surveyed for the "Seewerk" Falkenhagen was about nine square kilometers in size, of which just $8.24 \mathrm{~km}^{2}$ had been transferred to Montan in the land register on April 31, 1944. ${ }^{49}$ Originally, the area of the "Gut Falkenhagen" property had been $7.35 \mathrm{~km}^{2} .50$ That area included a site intended for a research institute on the former grounds of the Falkenhagen Castle. Montan had acquired, or intended to acquire, another $23.51 \mathrm{~km}^{2}$ in the Falkenhagen area, so that in the end it would have more than $31.75 \mathrm{~km}^{2}$.

In July 1943, the "Gesamtplanung Seewerk" (Overall Plan for the Lake Factory) included 5 groups of buildings (A-E), of which only Building Group D, the N-Stoff plant, was built at that time. These groups were to serve the following purposes ${ }^{51}$ :

- (A) General operations: Briesen train station, energy distribution, storage for raw materials, administration, main workshops (including transportation workshops), housing for factory security guards, cafeteria for the entire staff, and central kitchen to distribute food to the satellite kitchens.

- (B) Five scientific institutes with semitechnical testing facilities (by the lake).

- (C) Experimental field with "Sprenggarten" (detonation area) and shooting range.

- (D) N-Stoff plant.

- (E) Unknown, presumably later (S) for sarin.

\footnotetext{
${ }^{46}$ Klenck, Jürgen E. von, "History of the 'Seewerk' (Falkenhagen)," March 26, 1945, p. 3/71, The National Archives, London, WO 208/2186.

${ }^{47}$ Ibid., p. $1 / 69$.

48“"Die Deutsche Kampfstoff-Produktion,” Ludwigshafen am Rhein, February 1, 1944, p.7, BArch R3/1894.

${ }^{49}$ Entwurf eines Schreibens der Montan über Grunderwerb Falkenhagen, June 23. 1944, Preuss private collection.

${ }^{50}$ Anhang zum Bericht der Deutschen Revisions- und Treuhand-Aktiengesellschaft Berlin über die bei der Verwertungsgesellschaft für Montanindustrie $\mathrm{GmbH}$, Berlin-Charlottenburg, vorgenommene Sonderprüfung betr. Forstabteilung, p. 17, BArch Berlin, R 8135/4782.

${ }^{51}$ Baustelle Seewerk: Sachdarstellung über die Gesamtplanung, das Abrechnungswesen, das Sozialwesen, den Werkschutz, Werkfeuerwehr und Werkluftschutz, July 15, 1943, The National Archives, London, FO 1031/179.
} 


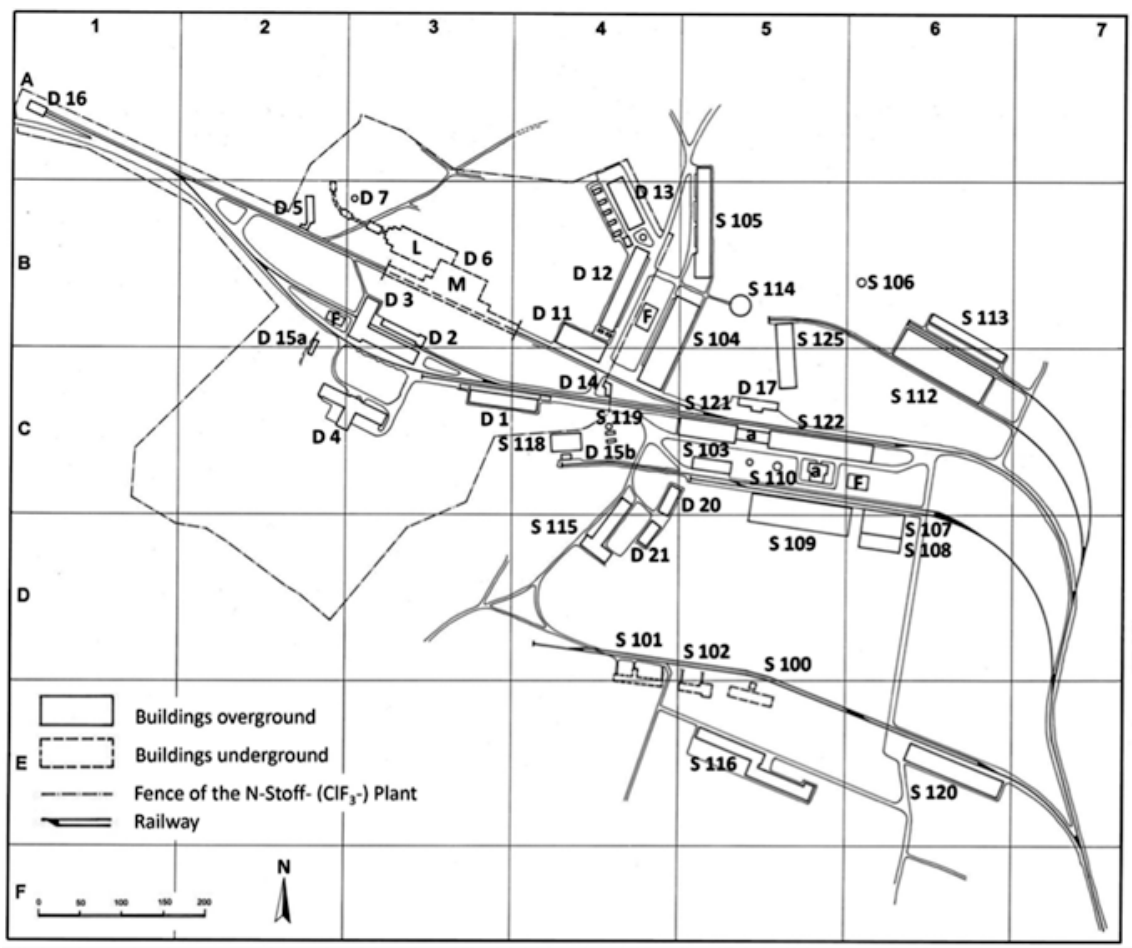

Fig. 3 Layout of Monturon GmbH Falkenhagen (“Seewerk”) (Gesamtlageplan - Seewerk S/o (M 1 : 2.500), Dipl. Ing. Max Haaf, Stuttgart, December 21, 1943, Preuss private collection)

In an overall site plan for the Seewerk (Falkenhagen) project of $1943,{ }^{52}$ the buildings of the factory are marked only with the letters D for the N-Stoff plant and $\mathrm{S}$ for the sarin plant.

The five scientific institutes (Building Group B) were located on the eastern shore of the Schwarzer See (Black Lake). There were laboratories and a vacuum tunnel to test the ballistic properties of a new type of weapon; these were also referred to as "Institut Ost" (East Institute). ${ }^{53}$

The function of the various buildings could be determined from the lists of buildings on the site plan. The lists of buildings were supplemented by evaluating other written sources (see Fig. 3, Table 7). ${ }^{54}$

\footnotetext{
${ }^{52}$ Gesamtlageplan-Seewerk S/o (M $\left.1: 2.500\right)$, Dipl. Ing. Max Haaf, Stuttgart, December 21, 1943 , Preuss private collection.

${ }^{53}$ Schreiben der Waffenamt-Forschungsabteilung (WaF), Nr. 595/39 gKdos Wa F/A2, an Wa J Rü 10 und Wa J Rü (Mun3) betreffend MO, Büro Prof. Loos. January 30, 1940, Preuss private collection. ${ }^{54}$ Bauvorhaben Seewerk, Zusammenstellung der bis zum 30.06.1943 angefallenen Kosten, The National Archives, London, FO 1031/179.
} 
Table 7 Inventory of buildings: Monturon GmbH Falkenhagen ("Seewerk")

\begin{tabular}{|c|c|c|c|}
\hline Building-No. & Function & Plant & Coordinates \\
\hline D 1 & Preparation & N-Stoff & C $3 / 4$ \\
\hline D 2 & Water purification plant & N-Stoff & B 3 \\
\hline D 3 & Workshop, central heating & N-Stoff & $\mathrm{B} / \mathrm{C} 3$ \\
\hline D 4 & Common room, administration & N-Stoff & C $2 / 3$ \\
\hline D 5 & Neutralization & N-Stoff & B 2 \\
\hline D 6 & Manufacturing plant L (Tanks) & N-Stoff & B $2 / 3$ \\
\hline D 6 & Manufacturing plant $\mathrm{M}$ & N-Stoff & B $2 / 3$ \\
\hline D 7 & High-level water tank & N-Stoff & B 3 \\
\hline D 8 & Workshop & N-Stoff & \\
\hline D 8a & Workshop & N-Stoff & \\
\hline D 9 & Storehouse & N-Stoff & \\
\hline D 9a & Storehouse & N-Stoff & \\
\hline D 10 & Defroster & N-Stoff & \\
\hline D 11 & Diesel powerhouse & N-Stoff & $\mathrm{B} / \mathrm{C} 4$ \\
\hline D 12 & Generator building & N-Stoff & B 4 \\
\hline D 13 & Apparatus building & N-Stoff & B 4 \\
\hline D 14 & Keeper's lodge & N-Stoff & C 4 \\
\hline D $15 a$ & Purification plant I & N-Stoff & $\mathrm{B} / \mathrm{C} 2$ \\
\hline D $15 b$ & Purification plant II & N-Stoff & C 4 \\
\hline D 16 & Locomotive shed & N-Stoff & A 1 \\
\hline D 17 & Garage & N-Stoff & C 5 \\
\hline D 18 & Pump room (lake) & & \\
\hline D 18a & Pump room & & \\
\hline D 20 & Laboratory & N-Stoff & C 4 \\
\hline D 21 & Laboratory school & N-Stoff & D 4 \\
\hline $\mathrm{F}$ & Static water tank & & \\
\hline S 100 & Storehouse (underground) & Sarin & E 5 \\
\hline S 101 & Storehouse with tanks & Sarin & D/E 4 \\
\hline S 102 & Storehouse with tanks & Sarin & E 5 \\
\hline S 103 & Storehouse with tanks & Sarin & C 5 \\
\hline S 104 & Manufacturing plant & Sarin & $\mathrm{B} / \mathrm{C} 4 / 5$ \\
\hline S 105 & Product purification & Sarin & $\mathrm{A} / \mathrm{B} 5$ \\
\hline S 106 & Chimney & Sarin & B 6 \\
\hline S 107 & Boiler house & Sarin & C/D 6 \\
\hline S 108 & Turbine house & Sarin & D 6 \\
\hline S 109 & Coal yard & Sarin & C/D 5 \\
\hline S 110 & Chloromethane gasometer & Sarin & C 5 \\
\hline S 111 & Storehouse & Sarin & \\
\hline S 112 & Filling plant & Sarin & $\mathrm{B} / \mathrm{C} 6$ \\
\hline S 113 & Product purification & Sarin & B/C 6 \\
\hline
\end{tabular}


Table 7 (continued)

\begin{tabular}{l|l|l|l}
\hline Building-No. & Function & Plant & Coordinates \\
\hline S 114 & Cooling tower & Sarin & B 5 \\
\hline S 115 & Special bath & Sarin & C/D 4 \\
\hline S 116 & Casualty ward & Sarin & E 5 \\
\hline S 117 & Chimney for acids & Sarin & C 5 \\
\hline S 118 & Sewage purification plant & Sarin & C 4 \\
\hline S 119 & Sewage purification plant & Sarin & C 4 \\
\hline S 120 & Warehouse & Sarin & E 6 \\
\hline S 121 & Manufacturing plant & Sarin & C 5 \\
\hline S 121 a & Manufacturing plant & Sarin & C 5 \\
\hline S 122 & Manufacturing plant & Sarin & C 5/6 \\
\hline S $122 a$ & Manufacturing plant & Sarin & C 5/6 \\
\hline S 123 & Mesh net station & Sarin & \\
\hline S 125 & HCl basin & Sarin & B/C 5 \\
\hline S 126 & Gas decomposition & Sarin & \\
\hline S 127 & Subway & Sarin & C 4
\end{tabular}

\section{The Development of N-Stoff Production}

In 1937 representatives of the Waffenamt visited the laboratories of IG Farbenindustrie AG in Leverkusen. The skin-damaging properties of chlorine trifluoride, and its reactivity when organic and inorganic materials combine with high heat or flame, attracted their interest. Between 1937 and 1944, between three and five metric tons of chlorine trifluoride, which had been produced in a small laboratory-sized plan in Leverkusen, were delivered to the OKH. The Waffenamt saw possible military applications as an incendiary material and later as filling for artillery shells, as propellant for underwater shells and ramjet torpedoes, and as a rocket fuel additive (Schmaltz 2005, 148). Interesting results from experiments with chlorine trifluoride led the research department of the Waffenamt to grant permission as early as 1938 to build a factory for its mass production in Falkenhagen. In addition to the large plant in Falkenhagen, a smaller experimental plant was built under the direction of the $\mathrm{OKH}$ on the Kummersdorf testing grounds in Gottow. It was said to have been in operation in $1943 .^{55}$

\footnotetext{
${ }^{55}$ Enemy Personnel Exploitation Section FIAT, Control Commission for Germany (BE), B.A.O.R. In FIAT EP 254-84 (von Klenck) 14. December 1945, Interrogation Report, pp. 16-19. The National Archives, London, FO 1031/97. Anonymus: Chlortrifluorid (ClF3), Anlage 9(5/-), p. 1p1-19, after 1945, Preuss private collection.
} 


\subsection{The Buildings of the N-Stoff Plant at the "Seewerk" Falkenhagen}

The buildings of the N-Stoff plant are identifiable in Fig. 3 by the initial letter D. They are located in the northwest of the factory grounds inside a fence around the manufacturing plant (D 6). The fenced area is entered via the gate (D 14). Purification plant II (D 15b), a garage (D 17), a laboratory building (D 20), and the laboratory school (D21) were located outside the fence. Located within the fence were, from northeast to southwest, the apparatus building (D 13), the generator building (D 12), the electrical center (D 11), and preparation (D 1). To the west of this last, followed the water purification plant (D 2), the workshop with the central heating, purification plant I (D 15a), and neutralization (D 5). The common building held, among other things, the cafeteria and the rooms for the administration (D 4). Buildings D 8, D 9, D 10, D 18, and D 19 were presumably located outside the area depicted on the factory plan.

\section{The Development of the Nerve Gases Tabun and Sarin}

In the pest control laboratory of the Elberfeld factory of IG Farbenindustrie AG in 1934 Gerhard Schrader began working on the development of a means to combat aphids. The Heereswaffenamt, to whom this invention was reported in 1935, showed interest. Laboratory experiments on its military usefulness followed in 1936. From 1939, the Wehrmacht conducted experiments with the new chemical weapon on its experimental grounds in Raubkammer, near Munster, and in the army's gas protection laboratory in Berlin-Spandau. The new chemical weapon was assigned the code names tabun, T-83, and $\mathrm{G}$ (for Gelan). A plant was built in Dyhernfurth to mass produce it, and from June 1942 to January 1945 a total of 12,753 metric tons of tabun were produced. ${ }^{56}$

In 1938, again in the Elberfeld factory of IG Farbenindustrie AG, Schrader developed another chemical weapon, which after several tests by the Heereswaffenamt was to begin mass production under the name sarin. The code name for sarin was T 46 . However, by 1945 just 0.5 metric tons of this chemical warfare agent could be produced in a pilot plant in Raubkammer. ${ }^{57}$

\footnotetext{
56“"Die Deutsche Kampfstoff-Produktion, Ludwigshafen am Rhein," February 1, 1944, p. 4, BArch R3/1894. Sonderausschuss C beim Reichsminister für Rüstung und Kriegsproduktion, Bericht über die Lage auf dem Kampfstoffsektor, Auszug aus dem Vortrag im Führerhauptquartier, May 15, 1943, mit einer Gegenüberstellung der Situation vom March 1, 1944, p. 6/32, BArch, R 3/1894. Aufstellung über K-Stoffe, Gesamtfertigung Stand December 1, 1944, p. 67, BArch R3/1894. Sonderausschuß C, Arbeitsbüro Dr. v. Klenck an Dr. Pfaundler, I.G. Frabenindustrie A.G. Produktionszahlen, December 1944, p. 93, BArch R3/1894.

${ }^{57}$ This is an occasion to point out that Eibl $(1999,157$ n. 217) wrote that, according to a statement given on the telephone by J. Preuss, some 50 metric tons of N-Stoff and some $500 \mathrm{~kg}$ of sarin had been produced in Falkenhagen. This is probably the result of a misunderstanding on the telephone, since the $500 \mathrm{~kg}$ of sarin should be credited to Plant R VIII in Munster. Hahn's unsourced
} 


\section{The Manufacturing Processes for Sarin}

The manufacturing process intended for Falkenhagen was based on the four-step salt method. ${ }^{58}$ Mass production of sarin was supposed to reach 500 metric tons monthly in Falkenhagen. A simplified four-step method was planned. The first step was to follow the procedure of IG; the second step could be avoided after a redesign of the chemical processes. The third step was supposed to be produced according to a process developed by the OKH. The production of the final stage - that is, sarin itself - was based on a continuous process that had been tested by the OKH in Building R VIII in Munster. The technical design of the processes and plants was to be in the hands of IG.

On the map of the buildings of the Falkenhagen factory (Fig. 3), the buildings of the sarin plant are identifiable by the initial letter $\mathrm{S}$. In addition to three manufacturing buildings (S 104, S 121, S 122), there are two buildings identified as purification buildings (S 105, S 113); located between the two were a cooling tower (S 114), a chimney (S 106), and a hydrochloric acid basin (S 125). The buildings numbered S 101, S 102, and S 103 had aboveground tanks; there was also an underground storehouse (S 100). There was additional storage in a warehouse (S 120), a chloromethane gasometer (S 110), and a coal yard (S 109). The last of these belonged functionally to the boiler house (S 107) and turbine house (S 108). A separate power plant was planned for the sarin plant. The sewage purification plants (S 118, S 119) would presumably have caused problems when operating the plant, because of the minimal slope. Because a filling plant (S 112) was planned, the dangerous chemical warfare agent sarin was to be filled in bombs and shells at the production facility itself, just like tabun in Dyhernfurth.

In the aerial photograph, another built area with connection to the railroad is identifiable south of the casualty ward (S 116) as well as one between the tank area and the coal yard (S 109). The broad curve of the railroad line is striking and suggests that additional plants were planned on the Falkenhagener Heide.

\section{Vereinigte Flussspatgruben GmbH in Stulln}

In November 1939 Montan was contracted by the Waffenamt to acquire fluorite mines in the Bavarian districts of Stulln, Lissenthan, and Brudersdorf (near Nabburg). There was particular interest in those owned by the Vereinigte

(Footnote 57 continued)

assertion that sarin production in Falkenhagen had "partially begun," Hahn $(1986,229)$ is likewise unprovable.

${ }^{58}$ Aktennotiz der I.G. Farbenindustrie Aktiengesellschaft, Ludwigshafen am Rhein, Zwischenprodukten-Gruppe, betreffend Sarin, July 21, 1943, The National Archives, London, FO 1031/179; Aktennotiz der I.G. Farbenindustrie Aktiengesellschaft, betreffend Sarin, Leverkusen, July 26, 1943, The National Archives, London, FO 1031/179; "Die Lage auf dem K-Stoffgebiet," December 1, 1942, BArch Berlin, R 3112/191. 
Flussspatgruben Lissenthan $\mathrm{GmbH} .{ }^{59}$ Fluorite is the raw material for hydrogen fluoride, which was an intermediate product in N-Stoff production. In the summer of 1942, following a meeting with the head of the central division of the Waffenamt, there was a plan to found a company with headquarters in Falkenhagen for M.O. Falkenhagen that would be merged with Vereinigte Flussspatgruben $\mathrm{GmbH}$, Nabburg, in order to ensure the supply of raw materials for the Falkenhagen factory. The firm Riedel de Haen AG, Berlin was contracted to manage in trust the building of a factory at Flussspatgruben GmbH in Stulln. Hence Riedel de Haen was also asked whether it was prepared to take over as leaseholder the management of the army-owned factory in Falkenhagen. ${ }^{60}$

After the war a team from the British Intelligence Objectives Sub-Committee (BIOS) visited the plant in Stulln. Its report indicates that it was not just a large plant to manufacture hydrofluoric acid and a replacement plant that had been built. The factory in Stulln was so large that it would also have been possible, using the equipment moved from Falkenhagen, to produce chlorine trifluoride (N-Stoff) in a quantity similar to that produced there. Glupe gave the BIOS team a tour of the factory in Stulln; in the text he is referred to as an employee of Riedel de Haen. According to his statements, he had built both the plant in Stulln and the one in Falkenhagen. After he transferred to the Waffen-SS, in October 1944 he had taken on the task of starting N-Stoff production in Falkenhagen for the SS. Glupe had developed the production process for chlorine trifluoride used in Falkenhagen in a laboratory at the Kaiser Wilhelm Institut für physikalische Chemie und Elektrochemie in Berlin. The next step was to build a somewhat larger plant in Gottow. Then Glupe could translate his findings and developments in Falkenhagen and in Stulln on a large technical scale (Schmaltz 2005, 145) ${ }^{61}$

\section{The Dyhernfurth Factory of Anorgana GmbH}

The site of the factory in Dyhernfurth (now Brzeg Dolny) was between the Oder River and the town of Seifersdorf (now Radecz). The properties were acquired by Montan beginning in 1940. The tabun plant began production in 1942; it was the

\footnotetext{
${ }^{59}$ Schreiben des Oberkommandos des Heeres (Ch H Rüst u BdE), Wa J Rü Stab IV d an das Oberkommando der Wehrmacht (OKW), W Stab W Rü, betreffend M.-O., Falkenhagen, Erwerb von Flussspatgruben, Antrag auf Bestimmung einer Bedarfsstelle, January 1940, Preuss private collection.

${ }^{60}$ Schreiben des Oberkommandos des Heeres (Ch H Rüst u BdE), 70 o 3018 Wa J Rü (Mun 3 zbV/VIII), Nr. 10006/43 g.Kdos., an I.D. Riedel - E. de Haen AG, Berlin-Britz betreffend Sonderbauvorhaben OKH, February 18, 1943, Preuss private collection.

${ }^{61}$ BIOS. Final report no. 1595, item no. 22, "German Fluorine and Fluoride Industry," London, p. 78, Preuss private collection; W. Archer, W. J. V Ward, and O. S. Whitson, "Hydrofluoric Acid, Vereinigte Flusspatgruben GmbH Stulln,” 1946, BIOS target no. C22/2012, C.I.O.S. Black List Item 22, Miscellaneous Chemicals, British Intelligence Objectives Sub-Committee, Preuss private collection.
} 
second-largest producer of a single chemical warfare agent. The operating company of the state-owned Montan plant was Anorgana $\mathrm{GmbH}$, a subsidiary of IG Farbenindustrie AG. The factory's capacity was 1,000 metric tons of tabun monthly in 1944. Altogether, from June 1942 to January 1945, 12,753 metric tons of tabun were produced and filled in bombs and shells. ${ }^{62}$ The capacity of the tabun filling plant was 770,000 shells for the light field howitzer (lFH $10.5 \mathrm{~cm}$ ), or 250,000 shells for the heavy field howitzer $(\mathrm{sFH} 15 \mathrm{~cm})$, or 12,500 bombs monthly. ${ }^{63}$ The map of the factory makes it clear that it was possible to store tabun and the intermediate products for it at the factory. The shells filled with tabun (Green Ring 3) were picked up by the army munitions facilities, which were responsible for chemical weapons, with munitions trains. Consequently, the filled Green Ring 3 bombs were sent to the air munitions institutions for which they were intended. Other chemical warfare agents produced in Dyhernfurth included cyanogen chloride ( $\mathrm{T}$ 150) beginning in 1943 or 1944, with a capacity of 20 metric tons monthly, and, in addition from 1943 or 1944 hydrogen cyanide (T 155) as well, with a capacity of 20 metric tons monthly, and Bi IV 99 (T 300), an alloy of arsenic, magnesium, and aluminum produced by wetting arsine. The planned capacity of $\mathrm{T}$ 300 production was 100 metric tons monthly. ${ }^{64}$ An experimental station for filling bombs with chemical warfare agents (e.g., Aeroform) in powder form was built at the end of the war in the HMa St. Georgen (Powder Filling Plant, Building W4 or 1003) (Preuss and Eitelberg 2001,162-65).

\section{The Filling and Storage of Chemical Weapons in the Munitions Facilities of the Army and Air Force}

With the exceptions of phosgene and tabun, chemical weapons were filled in five army and two air force munitions facilities. The bomb-filling plant in the Ammendorf factory was another exception, but it was active only until the Lufthauptmunitionsanstalt (LHMa; Main Airforce Munitions Facility) in Mockrehna, east of Leipzig, could be put into operation.

\footnotetext{
${ }^{62}$ List of K-Stoffe, total production as of December 1, 1944, p. 67. R3/1894; Report on the production of C-Stoffe, December 1944, p. 86, R3/1894.

${ }^{63}$ Oberkommando des Heeres (Ch.H.Rüst u. BdE.) Firma IG Farbenindustrie A.G. to the attention of the director, Dr. Ambros o.V. Ludwigshafen am Rhein, concerning the construction contract to build a factory to manufacture Product G, contract no. 9/IXa-240-9018/39, p. 1, The National Archives, London, FO 1031/223.

${ }^{64}$ E. Ehmann, U.S. Army Chemical Warfare Project, A.4, "Produktionsstätten und Produktionshöhen, a) Kampfstoffe," 1948, pp. 720-40, Preuss private collection; report (no. VI/ 11302) by the Deutschen Revisions- und Treuhand AG, Berlin, on the audit by Anorgana GmbH, Ludwigshafen a/Rh., Dyhernfurth factory, of the annual report on March 31, 1943, copy no. 1, p. 4, The National Archives, London, FO 1031/165.
} 
There were only seven filling plants for chemical weapons in the former German Reich. The first to be built was the filling plant of the HMa Munster, which can be considered the model for the filling plants of the HMa Löcknitz and the HMa St. Georgen (Traunreut). The third generation of buildings were the filling plants of the HMa Dessau and the HMa Lübbecke, which were considerably smaller. The filling plants planned for the Luftwaffe were the LHMa Mockrehna and the LHMa Oerrel (Dethlingen) (Preuss 2002; Preuss and Eitelberg 2003a, b). These plants were planned and built by Orgacid/Lonal.

\section{The Chemical Weapons Complex in Munster}

The chemical weapons complex in Munster was located within the Truppenübungsplatz Munster (Munster military training area), the history of which will be sketched below based on a Festschrift produced 1983 by the Kampftruppenschule 2 . $^{65}$

The moor, forest, and heath areas to the south and southwest of Munster, a small village on the around $40 \mathrm{~km}$ north of Celle on the Lüneburger Heide, were expanded from 1892 onward into a military training area of circa $49 \mathrm{~km}^{2}$. The first troops arrived on June 7, 1893. There they found around fifty newly constructed buildings, and that number grew over the next two decades until the beginning of the First World War to more than 144 buildings. In January 1916, construction began on another training area north of Munster, around Breloh and along the railroad line to Uelzen, in the forest area of Raubkammer. It was referred to as Munster-Nord (Munster-North) to distinguish it. Within this area, between the Heidkrug outwork to the east, Breloh to the west, and north of the railroad line to Uelzen, the Gasplatz Breloh (Breloh gas area), of around $4.4 \mathrm{~km}^{2}$, was built in 1917. It served as a filling plant for gas shells. In addition, field experiments with the use of chemical warfare agents were carried out in Munster-Nord. The Clark factory served to fill Blaukreuz munition. Grünkreuz (Green Cross) shells were produced in the Klopper factory, and Gelbkreuz (Yellow Cross) shells in the Lostwerk. The filling plants were headed by Dr. Hugo Stoltzenberg, who had also played a role in Munster after the First World War and in the secret rearmament between the wars (Stoltzenberg 1994, 333-34).

At the end of the First World War, the Gasplatz Breloh had around 48,000 metric tons of gas munitions and several thousand tons of seized munitions as well as 100 tank cars and containers with liquid chemical warfare agents. ${ }^{66}$

Of these, around a million chemical warfare shells and 230,000 chemical warfare mines as well as 40 tank cars and containers with chemical warfare agents were

\footnotetext{
${ }^{65}$ Spezialstab ATV, Gruppe Ausbildungsmaterial, Kampftruppenschule 2, 90 Jahre Truppenübungsplatz Munster, 1893-1983 (Munster 1983).

${ }^{66}$ Ibid., p. 24.
} 
exploded on October 24, 1919. In addition, 42 buildings of the Grünkreuzwerk and the Gelbkreuzwerk were destroyed. Around 950 metric tons of chemical warfare agents in liquid and solid form, which had been stored in approximately 60 tank cars, survived. The glass bottles filled with 500-1000 metric tons of Blaukreuz that had been uncovered when the munitions were dismantled were stored in Munster-Nord at this time. Because the remaining 60 tank cars were needed for other purposes, they were supposed to be emptied as quickly as possible. Hugo Stoltzenberg received instructions from the Reichstreuhandgesellschaft (Reich Trust Company) to destroy the chemical weapons. Previously, in a meeting between the Ministry of Finance, the Kaiser-Wilhelm-Institut für physikalische Chemie und Elektrochemie (Fritz Haber), the Ministries of Trade, Commerce, Transportation, and Labor, as well as the Reichstreuhandgesellschaft on October 28, 1920, there had been negotiations about how Stoltzenberg should destroy the chemical weapons. In the meeting, Privy Councilor Mente had described Dr. Stoltzenberg as very trustworthy. Haber explained that Stoltzenberg had worked under his direction and that he could give him the best recommendation. In a meeting on December 17, 1920 , it was revealed that Stoltzenberg had been director of the filling plant in Breloh during the war. In the meeting on October 28, 1920, the representative of the Reichstreuhandgesellschaft explained that it was estimated that 1,000 metric tons of gas artillery shells and cylinders (filled with Blaukreuz) were scattered about the German Reich. "In total, there ca. 2,000,000 such shells in around 35 locations. Of those 500-600,000 were stored in Unterlüss." ${ }^{67}$ It is largely unknown what happened with those shells. Hence the discussions that follow are still significant today. There are three types of sites for burying gas shells and cylinders filled with Blaukreuz, in which they have also demonstrably been found.

First, factories in which, during the First World War, chemical warfare agents had been produced and filled in glass bottles, metal containers or shells, and the filling plants in which glass bottles and metal containers filled with Blaukreuz were inserted into empty shells and covered with explosives (15 sites). Examples: At the former chemical factory of E.-Schering AG in Berlin, several thousand 10-centimeter Gelbkreuz shells from the First World War were buried in three pits after the Second World War. In Wahn, near Cologne, in 1976, 1064 drums of $200 \mathrm{~L}$ each were filled with Clark bottles from the First World War and brought to the mine in Herfa-Neurode. Secondly, it is to be expected that agents and munitions were buried at former dismantling sites as well, where, according to existing files, more than 25,000 gas shells were present (31 sites). ${ }^{68}$ Example: In Hallschlag, after

\footnotetext{
${ }^{67}$ Besprechung im Reichsschatzministerium III betr. Gasplatz Breloh, unter Vorsitz des Herrn Ministerialdirektors Kautz, October 28, 1920, BArch R 2201/3305; HQ-ETO-US-Army CWS, War Office, "Intelligence Division Report, no. 3961" Report on German CW Dump at Münster-Ost" (= Munster), June 23, 1945, National Archives, Washington, DC., RG 338; Bericht über die Vernichtung von Gas-Kampfstoffen, Berlin, December 17, 1920, BArch, R 2201/3305.

${ }^{68}$ Reichsschatzministerium, Listen der Orte, an denen Zerlegungsarbeiten von Munition vorgenommen wurden oder wo dies beabsichtigt ist, 1. Zerlegestelle für Eisenmunition und Metallkartuschen (1919-22), BArch 2201-Nr. 3225.
} 
the First World War, some 950,000 shells were dismantled, of which around $1.3 \%$ were filled with chemical warfare agents. Most of them were destroyed in Hallschlag as well. Intense research in the 1990s was able to identify another circa 500 shells from the First World War.

Thirdly, chemical warfare agents have also been found at sites where they were supposed to be used for commercial purposes after the First World War. For example, Monzingen, near Bad Kreuznach, where 8,000 glass bottles filled with Blaukreuz and $30,0007.5-\mathrm{cm}$ shells filled with phosgene had been buried and were uncovered after the Second World War. The Stolzenberg factory in Hamburg is another example.

Even after the explosion in Munster, additional chemical munitions were brought to Munster from dismantling sites in the 1920 s to be dismantled or exploded as part of contracts between the Reichsschatzamt and Evaporator AG. It is not known whether all 35 dismantling sites delivered shells with chemical munitions and filled glass bottles to Evaporator AG. It is, however, known that shells and/or glass bottles with chemical warfare agents were buried at some of these sites.

From 1934-35, the Munster-Nord exercise area was reconverted into a testing ground for chemical warfare agents and from 1939 onward expanded to $108 \mathrm{~km}^{2}{ }^{69}$

On April 17, 1945, Munster was occupied by British troops, who found several large facilities for chemical warfare agents in its forests. These included the Raubkammer military exercise area with the Raubkammer army experimental site and the Munster-Nord filling plant as well as the air force testing site of Munster-Nord, the HMa Munster-Ost, the LHMa Örrel, and various facilities of the Nebeltruppen (smoke-mortar troops). To the surprise of the British, however, there were also employees and documents from the Heereswaffenamt and the army's gas-protection laboratory in Berlin-Spandau found in Munster, where they had been moved to protect them from bombing and the approaching Soviet troops. ${ }^{70}$

Directly north of Munster, the British discovered the Munster-Raubkammer (Munster-Nord) military exercise area, which was around $16 \mathrm{~km}$ long and $8 \mathrm{~km}$ wide and covered with pines and heather. Roughly in its center was a large testing ground for chemical artillery and to the east of that a place to drop chemical bombs. The Heeresversuchsstelle Raubkammer (Raubkammer Army Testing Grounds), including several buildings, was located in the southwest part of Munster-Nord. It was subdivided into Bereiche (areas), which were numbered from R I to R IX, not including the administration. Bereich R I was responsible for field testing and photographic documentation. Bereich R II had the chemistry laboratory. Bereich R III consisted of several buildings for decontamination, gas detection, and the maintenance and repair of

\footnotetext{
${ }^{69}$ Spezialstab ATV, Gruppe Ausbildungsmaterial, Kampftruppenschule 2, 90 Jahre Truppenübungsplatz Munster, 1893-1983 (Munster 1983), pp. 33, 54.

70" Report on the C. W. Experimental Station at Raubkammer bei Munster and related Establishments," 1945, C.D.R-5. Enemy C. W. and Smoke Intelligence Summary, no. 83, The National Archives, London, WO 208/3576; A. K. Mills, "Investigation of Chemical Warfare Installations in the Munsterlager Area, including Raubkammer," 1945, report no. XXXI-86, CIOS Item 8, Chemical Warfare, Combined Intelligence Objectives Sub-Committee (CIOS), G-2 Division, SHAEF (Rear) APO 413, Preuss private collection.
} 
protective clothing. Bereich R IV had parking garages and an auto repair shop. In Bereich R V, medical aspects of the field tests and toxicology were studied, and R VII was the medical area. East of this complex of related buildings was Bereich R VI, which measured around 600 by 400 meters and was an experimental plant for the production of chemical munitions, with equipment to melt and mold chemical agents and to manufacture munitions. In addition, experiments with hot and cold storage were conducted in this area, and munitions and chemical agents could be stored in six munitions buildings and six warehouses respectively. East of that, between R VI and R VIII, was the Nebelfüllstelle (Smoke Filling Plant) Munster-Nord. The Nebel (smoke) was replacing the term Kampfstoff (chemical warfare agent). Initially, it was used for testing filling methods for chemical warfare agents. Increasingly, however, the plant was used for ordinary filling work. In addition to the Nebelfüllstelle in Munster, there were chemical filling plants for the army in St. Georgen, Löcknitz, Dessau, and Lübbecke. The plant at Lübbecke, however, was partially functional, but was never in operation (Preuss und Eitelberg 2003a, 164). The air force also had a filling plant in Mockrehna and one in Örrel. The Nebelfüllstelle in Munster had around 60 buildings. The central plant was the bunker for chemical agents, with eight tanks holding 450 cubic meters of chemical agents each (a maximum of ca. 4700 metric tons) and two filling buildings. Füllhaus I had two automatic filling machines for shells, below which were twelve tanks for intermediate storage of mustard gas and arsine oil. In Füllhaus II stood two semiautomatic filling machines for $15-\mathrm{cm}$ rockets and four semiautomatic machines for shells. Three buildings were available for preparing and finishing munitions.

The testing site for the air force was immediately adjacent. This post consisted of five small and one medium-sized two-story buildings. Their task was to develop additional ways for the air force to employ chemical warfare agents. In addition to a laboratory and rooms for filling and testing bombs, spraying and molding equipment for liquid chemical agents was studied and tested. Outside the buildings, the British found 250-kg bombs marked with three green rings. They claimed they had contained sarin that had been destroyed shortly before the Allies arrived. In fact, however, the three green rings indicated they were filled with tabun (Preuss and Eitelberg 2003a, 414). Sarin would have been marked with five green rings. A little farther to the east followed Bereiche $\mathrm{R}$ VIII (Vorwerk Heidkrug), which was camouflaged to look like a farm. For a time, tabun, excelsior (10 metric tons), and sarin (0.5 metric tons) were produced there in small quantities in succession. Bereich R IX housed animals and facilities for animal experiments. On the grounds of Munster-Nord, there were more than ten areas for testing and experimenting the use of chemical munitions and decontaminants.

Southeast of Munster was the LHMa Örrel. The British found 131,000 bombs of various sizes there, stored in bunkers. There was also a mustard gas filling plant for 250 and $500 \mathrm{~kg}$ bombs with two semiautomatic filling machines and one destroyed mobile filling plant for mustard gas, mounted on a railroad car; additional mobile filling plants were said to have been stationed in St. Georgen and Löcknitz. ${ }^{71}$

\footnotetext{
${ }^{71}$ A.K. Mills, "Investigation of Chemical Warfare Installations in the Munsterlager Area, including Raubkammer," report no. XXXI-86, CIOS Item 8, Chemical Warfare, Combined Intelligence
} 
The Heeresmunitionsanstalt Munster-Ost was located about two kilometers southwest of Munster. It had around 17,000 metric tons of chemical munitions in the form of 763,580 filled gas shells and rockets and 7000 bombs. $^{72}$

In November 1945 quantities of unfilled mustard gas in Munster were burned in a continuous process in an open trough. It was located 20-25 $\mathrm{m}$ from the mustard gas bunker of the Nebelfüllstelle. It was determined that arsenic compounds could be burned together with it. In addition, the contents of a large number of Italian oneand two-ton mustard gas containers were burned. They were stored outdoors and in warehouses. The incineration of chemical warfare agents was proposed by the British as a way of destroying chemical agents in the American zone as well. They were so convinced of this method that they also used it for British chemical warfare agents (mustard gas, lewisite) in the Bowes Moor munitions depot of the R.A.F. ${ }^{73}$

After the war, the heavy contamination of many areas prevented the use of the Truppenübungsplatz Munster-Nord for military training purposes. For that reason, efforts to study and decontaminate the grounds began in 1950. At first, the areas cleared for use were used only by British troops for exercises. In 1954, the Bundeswehr took over the grounds, and so from May 1956 German soldiers were trained there as well. At the same time, the Entgiftungskommando Raubkammer (Raubkammer Decontamination Command) was working on removing chemical traces from two world wars. The pressure on the Entgiftungskommando was great, because there was a lack of training areas at the time. That led to chemical munitions that had already been removed being transported to another site to be dismantled. In Munster, by April 1960, after thirty-eight months, $38 \mathrm{~km}^{2}$ of contaminated grounds had been scoured by 60-70 employees, removing circa 48,000 shells, bombs, and containers for chemical warfare agents. ${ }^{74}$ Even after that, however, parts of the site were considered unsafe, so that a small group continued to remove munitions from the First and Second World War from the military training area.

On September 6, 1979, these specialists had an opportunity to be active in the civilian realm as well, when a child playing near the former site of the Chemische Fabrik Dr. Hugo Stoltzenberg in Hamburg was fatally injured. The Bundeswehr bomb disposal group from Munster was brought into investigate the grounds. It found circa 100 metric tons of munitions and chemicals on the abandoned industrial

(Footnote 71 continued)

Objectives Sub-Committee (CIOS), G-2 Division, SHAEF (Rear) APO 413, Preuss private collection.

${ }^{72}$ HQ-ETO-US-Army CWS, The War Office: Intelligence Division Report No. 3961, Report on German CW Dump at Münster-Ost (= Munster), June 23, 1945. National Archives, Washington, DC, RG 338.

${ }^{73}$ Williams, C., Burning of Mustard Gas and Lewisite at N0. 81 M.U., R.A.F., Bowes Moor, Estimation of Risk. Summary of Porton Report No. 2744. 1947. National Archives, Washington, DC., RG 338.

${ }^{74}$ Spezialstab ATV, Gruppe Ausbildungsmaterial, Kampftruppenschule 2, 90 Jahre Truppenübungsplatz Munster, 1893-1983 (Munster 1983), pp. 49-50. 
site (Scholz 2004). Dr. Hugo Stoltzenberg had attracted attention previously, because in 1928 a phosgene cloud was emitted from a tank car on his factory grounds that injured and even killed people. ${ }^{75}$

The Stoltzenberg factory drew attention again when the British visited it on June 21,1945 , and found dangerous chemicals, hand grenades filled with Blaukreuz and Weisskreuz, as well as smoke candles, incendiary materials, chemical warfare agents for training purposes, and 100 one-liter bottles with chloropicrin (PS). After his work in Breloh during and after the First World War, Stoltzenberg, probably on the recommendation of Fritz Haber, worked as a specialist in chemical warfare agents and munitions in a chemical factory in Hamburg and built chemical plants in Russia, Yugoslavia, Brazil, and Spain and hence participated in secret projects of the Reichswehr. ${ }^{76}$

The removal of munitions from the First and Second World War in Breloh continued in the 1980s. A first incineration plant was built for the destruction of chemical warfare agents. The second plant, which met all the requirements of the authorities, was operated by a federal organization: the Gesellschaft zur Entsorgung von chemischen Kampfstoffen und Rüstungsaltlasten mbH (GEKA mbH); (limited company for the removal of chemical warfare agents and armaments waste). With its 150 employees, it is capable of incinerating shells up to a caliber of $15 \mathrm{~cm}$ without dismantling them. It has facilities to clean contaminated soil, a plasma plant, a detonation chamber, and facilities to dismantle munitions. In terms of its construction, the facility is pioneering, and it also deals with munitions and excavated soil from other former munitions locations in Germany and abroad.

\section{Other Munitions Sites with Filling Plants for Chemical Weapons}

After the war and during the initial phase of the Allied occupation, large quantities of munitions were located in sites for chemical weapons that had filling plants. In the HMa Lübbecke, from April to August 1945, a total of 530,000 shells and mines with chemical warfare agents were stored, 117,000 of which were from Italy (Preuss and Eitelberg 2003b, 351). In the HMa St. Georgen, as a result of the United States Army's collection actions, 1,655,000 chemical shells and mines were

\footnotetext{
75، Note de la Delegation Française au sujet de l'explosion de gaz phosgens à Hambourg," June 14, 1928, "Notes d'un Secretair prises au cours d'un réunion tenne au Quai d'Orsay le lundi, December 3, 1928, Service historique de la Défense, Vincennes, 4N91 Dossier 1 Conférence des Ambassadeurs.

${ }^{76}$ Chemische Fabrik Dr. Hugo Stoltzenberg, Hamburg, Germany, Intelligence Division Report No. 3953, CIOS, Headquarters European Theater of Operations United States Army Chemical Warfare Service. National Archives, Washington, DC, RG 338.
} 
stored, along with 5870 metric tons of unfilled German chemical agents and $1600 \mathrm{~m}^{3}$ (ca. 2100 metric tons) Italian and Hungarian chemical agents in drums (Preuss and Eitelberg 2001, 204, 216).

The enormous quantity of Germany munitions but also the battlefield munitions of the Allies were dismantled or exploded in Germany. Large quantities were sunk at sea by order of the Allies (Frondorf 1993). ${ }^{77}$

\section{Dismantling Work After the First World War}

All of the dismantling work after the First World War was done under contracts between either states or the occupying armies and private companies. One example of this is the former factory of Espagit AG in Hallschlag, where 992,000 shells were dismantled after the First World War, 23,800 of which were gas shells. This factory was also ultimately destroyed by a large explosion (Preuss and Eitelberg 1999) It took years to collection the munitions that had been scattered by explosions. The project of studying the site in Hallschlag and making it safe cost around 50 million euros in the 1990s.

\section{Summary and Prospects}

The production of the chemical weapons industry and the processing and storage of its products cost many human lives and hundreds of millions of reichsmarks by the end of the Second World War. Even today, considerable funds have to be spent removing old munitions and waste left over from the production of chemical armaments in the First and Second World Wars from the soils and groundwater. The front lines - of the First World War, for example - were never thoroughly cleaned up because the project seemed hopeless; instead, in large areas only superficial cleanup was done. However, initial steps in this direction can be observed (Hubé 2016). The areas affected in that period are in Belgium, France, Italy, and Poland. The "Zone Rouge" identified in France after the First World War measured around $10,000 \mathrm{~km}^{2}$. Even today, it is largely reserved for forestry.

After a century, isn't it time to set ourselves the task of removing the remains of the two world wars in European solidarity using modern concepts and methods?

\footnotetext{
${ }^{77}$ See also: The History of Captured Enemy Toxic Munitions in the American Zone, European Theater, May 1945 to June 1947, Section VI Operation Davey Jones Locker, Chemical Corps 1946. Office of the Chief of Chemical Corps, Headquarters European Command, Preuss private collection.
} 


\section{References and Source Materials}

Aktennotiz der IG Farbenindustrie Aktiengesellschaft, betreffend Sarin, Leverkusen, July 26, 1943. The National Archives, London, FO 1031/179.

Aktennotiz der IG Farbenindustrie Aktiengesellschaft, Ludwigshafen am Rhein, Zwischenprodukten-Gruppe, betreffend Sarin. July 21, 1943. The National Archives, London, FO 1031/179.

Aktennotiz des Wa J Rü (Mun), Az. 70 o 40-19 Wa J Rü/Mun 3 zbV/IX, Nr. 1320/43 g.Kdos. betreffend die Ausweichstelle des Reichsamtes für Wirtschaftsausbau in Falkenhagen. July 26, 1943. Private Collection Preuss.

Aktenvermerk (Nr. 8) der IVG betreffend nach Stulln verlagertes Gut aus Falkenhagen. May 23, 1952. Private Collection Preuss.

Aktenvermerk der Montan betreffend Seewerk. July 25, 1944. Private Collection Preuss.

Anhang zum Bericht der Deutschen Revisions- und Treuhand-Aktiengesellschaft Berlin über die bei der Verwertungsgesellschaft für Montanindustrie $\mathrm{GmbH}$, Berlin-Charlottenburg, vorgenommene Sonderprüfung betr. Forstabteilung, BArch Berlin, R 8125/1691.

Anonymus, Chlortrifluorid (ClF3), Anlage 9(5/-), p. 9-11, post 1945. Private Collection Preuss.

Arbeitsberichte Chemie Werk Kapen, Seite 1247 (April 17, 1957), 1249 (February 11, 1957), 1722 (February 2, 1957) sowie Zusammenfassungen von Berichten zwischen dem January 29, 1953 und dem July 23, 1956, Private Collection Preuss.

Archer, W., W.J.V. Ward and O.S. Whitson, Hydrofluric Acid, Vereinigte Flusspatgruben G.m.b. H. Stulln. 1946. BIOS Target No. C22/2012, C.I.O.S. Black List Item 22, Miscellaneous Chemicals, British Intelligence Objectives Sub-Committee. Private Collection Preuss.

BIOS. Final Report No. 1595, Item No. 22, Carter, W. J., M. A. Howick, J. R. Burston, R. Y. Eagers and A. B. Crooks, German Fluorine and Fluoride Industry, London 1945, Private Collection Preuss.

Bausinger, Tobias. 2007. Ausbreitung von Nitroaromaten über das Sickerwasser der ehemaligen Espagit AG in Hallschlag. Ein Beitrag zur geoökologischen Bewertung eines kontaminierten Standortes. PhD dissertation, University of Mainz.

Bausinger, Tobias, Ulrich Dehner, and Johannes Preuss. 2005. Nitrodiphenylaminen und verwandten Verbindungen im Sickerwasser einer Rüstungsaltlast. Umweltwissenschaften und Schadstoff-Forschung 17 (1): 7-12.

Baustelle Seewerk: Sachdarstellung über die Gesamtplanung, das Abrechnungswesen, das Sozialwesen, den Werkschutz, Werkfeuerwehr und Werkluftschutz. July 15, 1943. The National Archives, London, FO 1031/179.

Bauvorhaben Seewerk, Zusammenstellung der bis zum 30.06,1943 angefallenen Kosten. The National Archives, London, FO 1031/179.

Bericht über die Deutsche Kampfstoff-Produktion. February 1, 1944. BArch Berlin, R3/1894.

Bericht über die Lage auf dem K-Stoffgebiet. December 1, 1942. BArch R 3112/191.

Bericht über die Vernichtung von Gas-Kampfstoffen, Berlin, December 17, 1920. Bundesarchiv, BArch Berlin, R 2201/3305.

Besprechung im Reichsschatzministerium III betr. Gasplatz Breloh, unter Vorsitz des Herrn Ministerialdirektors Kautz. October 28, 1920. Bundesarchiv, BArch R 2201/3305.

Boyne, J.G., E.W. Lanfear, W.S. Calcott, and P.J. Leaper. 1945. Production of Vesicant Agents at Ammendorf. M52.D92., CIOS Target No. 8/30 Chemical Warfare, Item No. 8, File No XXXII-7, Combined Intelligence Objektives Sub-Committee G-2 Division, SHAEF (Rear) APO 413, National Archives, Washington, RG 338 and British Library, Document Supply Center, Boston Spa.

Brauch, Hans Günter, and Rolf-Dieter Müller (eds.). 1985. Chemische Kriegführung. Chemische Abrüstung. Dokumente und Kommentare. Berlin: Berlin Verlag Arno Spitz.

Bundesarchive Koblenz und Freiburg. 1979. Fertigung, Lagerung und Beseitigung chemischer Kampfstoffe unter besonderer Berücksichtigung des Territoriums der Bundesrepublik Deutschland. BArch Koblenz, 35 pages. Private Collection Preuss. 
Burning of Bulk Mustard, Raubkammer, Germany, HQ-ETO (REAR) CWS-APO No. 887 to Chief CW Officer. November 6, 1945. National Archives, Washington, DC., RG 338.

Chemische Fabrik -Dr. Hugo Stoltzenberg, Hamburg, Germany, Intelligence Division Report No. 3953, CIOS, Headquarters European Theater of Operations United States Army Chemical Warfare Service. June 21, 1945. National Archives, Washington, DC., RG 338.

Der deutsch-französische Krieg 1870-71. 1881. Redigiert von der kriegsgeschichtlichen Abteilung des großen Generalstabes. Zweiter Teil. Geschichte des Krieges gegen die Republik. Dritter Band, des Gesamtwerkes V. Band. Berlin: Mittler.

Ehmann, Emil. 1948. U.S. Army Chemical Warfare Project, A.4. Produktionsstätten und Produktionshöhen, a) Kampfstoffe, 720-740. Private Collection Preuss.

Eibl, Christina. 1999. Der Physikochemiker Peter Adolf Thiessen als Wissenschaftsorganisator (1899-1990). Eine biographische Studie. Diss. phil. Dreieich: Historical Institute of the University of Stuttgart, Abteilung für Geschichte der Naturwissenschaften und Technik.

Entwürfe der Schreiben von Wa B 4 VII an die Orgacid GmbH, Vorbescheide zur Errichtung von Anlage, December 10, 1934. National Archive, London, FO 1031/204.

Frondorf, Mark J. 1993. Special Study on the Sea Disposal of Chemical Munitions. Science Applicatios International Corporation, Sponsored by U.S. Arms Control and Disarmament Agency, Contract Number: AC92RC1005, Task Order: 92-01, Mclean, Virginia.

Gesamtlageplan-Seewerk S/O (M 1: 2,500). December 21, 1943. Private Collection Preuss.

Gesellschaftsvertrag: Urkunde Nr. 331/1934, Notar Dr. F. Jacke. November 23, 1934. Private Collection Preuss.

Griess, T.E. (ed.). 1985. Atlas for the Second World War, Europe and the Mediterranean. Wayne: Avery Publishing Group.

Gutachten Nr 48. Entwurf eines Bau- und Errichtungsauftrages für die Errichtung der Sarin II Anlage in Seewerk (Auftrags-Nr. 3/IX-4888-9026/43), ohne Datum. The National Archives, London, FO 1031/179.

Hahn, Friedrich. 1986. Waffen und Geheimwaffen des Deutschen Heeres 1933-1945. Band 1: Infanteriewaffen, Pionierwaffen, Artilleriewaffen, Pulver, Spreng- und Kampfstoffe. Koblenz: Bernhard \& Graefe Verlag.

HQ-ETO-US-Army CWS, The War Office: Intelligence Division Report No. 3961, Report on German CW Dump at Münster-Ost (= Munster-Ost), June 23, 1945. National Archives, Washington, DC. RG 338.

Hubé, Daniel. 2016. Sur les traces d'un secret enfoui-Enquete sur l'heritage toxique de la Grande Guerre. Préface de Jean-Yves Le Naour. Paris: Michalon Éditeur.

Klenck, Jürgen E. von. 1945. History of the 'Seewerk' (Falkenhagen), The National Archives, London, WO 208/2186.

König, Wolfram and Ulrich Schneider. 1985. Sprengstoff aus Hirschhagen. Vergangenheit und Gegenwart einer Munitionsfabrik. Nationalsozialismus in Nordhessen, Bd. 8. Kassel: Verlag Gesamthochschulbibliothek Kassel.

Lebenslauf Max Zeidelhack. March 27, 1948. Bayerisches Hauptstaatsarchiv München, Office of Military Government, Bavaria, 13/83-2/5, National Archives, Microfilm Publication 12065 Section 3-402/NNDG No. 775037).

Lebenslauf von Prof. Dr. H. Engelhard, February 15, 1960, Universitätsarchiv Göttingen, UAG-Kur. 10221.

Mense-Stefan, Anne. 2005. Standortdifferenzierte Abschätzung von Sickerwasserraten in Hessen. Ein Beitrag zur Ermittlung von Stofffrachten aus dem Boden. PhD diss. University of Mainz, Mainzer Geographische Studien, Bd. 53.

Mills, A.K., Investigation of Chemical Warfare Installations in the Munsterlager Area, including Raubkammer. 1945. Report No. XXXI-86, CIOS Item 8, Chemical Warfare, Combined Intelligence Objektives Sub-Committee (CIOS), G-2 Division, SHAEF (Rear) APO 413, Private Collection Preuss.

Monturon GmbH, Aufstellung des Buchwertes zum 31.03,1944 (= Anschaffungswert 1944), Werk Falkenhagen. Private Collection Preuss. 
Monturon GmbH. Abschlussbericht 1943/1944, Fabrikhauptbuch Seewerk. Private Collection Preuss.

Note de la Delegation Francaise au sujet de l'explosion de gaz phosgens à Hambourg. June 14, 1928. Notes d'un Secretair prises au cours d'un réunion tenne au Quai d'Orsay le lundi 3. Dez. 1928. Service historique de la Défense, Vincennes, 4N91 Dossier 1 Conférence des Ambassadeurs.

Note de la Delegation Francaise au sujet de l'explosion de gaz phosgens à Hambourg. June 14, 1928. Notes d'un Secretair prises au cours d'un réunion tenne au Quai d'Orsay le lundi 3. Dez. 1928. Service historique de la Défense, Vincennes, 4N91 Dossier 1 Conférence des Ambassadeurs.Orgacid GmbH. Bericht über das Geschäftsjahr 1937/38. December 21, 1938. Private Collection Preuss.

Oberkommando des Heeres (Ch.H.Rüst u. BdE.) Firma IG Farbenindustrie A.G. to the attention of the director, Dr. Ambros o.V. Ludwigshafen am Rhein, concerning the construction contract to build a factory to manufacture Product G, contract no. 9/IXa-240-9018/39, p. 1, The National Archives, London, FO 1031/223.

Orgacid GmbH. Bericht über das Geschäftsjahr 1938/39. December 21, 1939. Private Collection Preuss.

Orgacid GmbH. Bericht über das Geschäftsjahr 1939/40. 1939. Private Collection Preuss.

Orgacid GmbH. Vorläufiger Geschäftsbericht über das Geschäftsjahr 1940/41. From April 1, 1941 to December 31 1940. Private Collection Preuss.

Orgacid GmbH. Vorläufiger Geschäftsbericht über das Geschäftsjahr 1941/42. From April 1, 1941 to December 31 1941. Private Collection Preuss.

Orgacid GmbH, Bericht über das Geschäftsjahr 1943-44. Private Collection Preuss.

Preuss, Johannes. 1990. Vorerkundungen und Bewertungen des Gefährdungspotenzials altlastenverdächtiger Betriebsflächen der ehemaligen Rüstungsindustrie - Stadtallendorf, Landkreis Marburg, Biedenkopf. Postdoctoral thesis, University of Marburg, unpublished.

Preuss, Johannes. 2002. Zahlencode-System des Heeres von 1925 bis 1940. Schwäbisch-Hall: Journal Verlag Schwend.

Preuss, Johannes, Ulrich Dehner and Frank Eitelberg, et al. 1994. Erkundung und Rekonstruktion des ehemaligen Werkes der Deutschen Sprengchemie (DSC) Werk Kraiburg, (unpublished for Stadtverwaltung Waldkraiburg).

Preuss, Johannes und Frank Eitelberg. 1994. Rekonstruktion der ehemaligen Fabrik zur Herstellung von Brand- und Kampfstoff: N-Stoff und Sarin der Monturon GmbH in Falkenhagen. Mainz: Johannes-Gutenberg-Universität Mainz, Geographisches Institut, (unpublished for Landesbauamt Frankfut/Oder).

Preuss, Johannes und Frank Eitelberg. 1996. Ehemalige Anlagen und Produktionsverfahren auf Rüstungsaltstandorten und ihre Bewertung. Handbuch Altlasten, Bd. 4 Wiesbaden: HLUG.

Preuss, Johannes und Frank Eitelberg. 1999. Hallschlag. Historisch-genetische Studie zur ehemaligen Fabrik für die Herstellung von Trinitrotoluol, Dinitrobenzol und Presskörpern aus Sprengstoffen sowie zur Verfüllung und Entlaborierung von Munition der ESPAGIT AG. Mainzer Geographische Studien, Bd. 45. Mainz: Johannes-Gutenberg-Universität Mainz, Geographisches Institut.

Preuss, Johannes und Frank Eitelberg. 2001. Historisch-genetische Studie über die ehemalige Heeres-Munitionsanstalt St. Georgen, (unpublished for Stadtverwaltung Traunreut).

Preuss, Johannes und Frank Eitelberg. 2003a. Heeres-Munitionsanstalt Lübbecke. Vorgeschichte der Stadt Espelkamp. Mainzer Geographische Studien, Sonderband 1. Mainz: Johannes-Gutenberg-Universität Mainz, Geographisches Institut.

Preuss, Johannes und Frank Eitelberg. 2003b. Vertiefende Historisch-Genetische Studie und Geländebegehung über die ehemalige Kampfstoff-Füllstelle der HMa Dessau (Kapen), (unpublished for Landesanstalt für Altlastenfreistellung, Magdeburg).

Preuss, Johannes and Frank Eitelberg. 2009. Das Werk Kraiburg der Deutschen Sprengchemie GmbH 1938-1945. Waldkraiburg schaut zurück. Geschichte einer jungen Stadt. 2nd rev. ed., Stadt Waldkraiburg. 
Preuss, Johannes und Frank Eitelberg. 2010. Die TEUTO-Metallwerke GmbH in Osnabrück. Rekonstruktion einer Fabrik für Infanteriemunition und Hülsen für Bordwaffenmunition der Jahre 1935-1945. Mainzer Geographische Studien, Sonderband 6, Mainz: Johannes-Gutenberg-Universität Mainz, Geographisches Institut.

Preuss, Johannes, Frank Eitelberg, Gerd Albrecht, et al. 2002. Modellhafte Altlastenuntersuchung an ausgewählten Standorten der Munitionszerlegung und -vernichtung nach dem Ersten Weltkrieg. UBA Text 49(2): 141 pages.

Preuss, Johannes, Frank Eitelberg, and Tania Bader-Nia, et al. 1993. Erkundung und Rekonstruktion des ehemaligen Werkes der Westfälisch Anhaltinischen Sprengstoff AG (WASAG) in Reinsdorf, Lutherstadt Wittenberge, (unpublished for Stadtverwaltung Wittenberg), 2 vols.

Preuss, Johannes, Frank Eitelberg and Wolfgang Form. 1992. Rüstungsaltstandorte und Verdachtsflächen in Hessen (1. und 2. Weltkrieg), (unpublished for Hessisches Ministerium für Umwelt, Reaktorsicherheit und Bundesangelegenheiten).

Preuss, Johannes, Frank Eitelberg and Peter Wilmes. 1992. Rekonstruktion der ehemaligen Rüstungsbetriebe in Geretsried - Deutsche Sprengchemie (DSC) Geretsried und Dynamit Actien Gesellschaft - Gesellschaft zur Verwertung Chemischer Erzeugnisse (DAG/Verwert) Wolfratshausen, (unpublished for Stadtverwaltung Geretsried).

Preuss, Johannes and Ulrich Schneider. 2005. Rüstungsaltlasten in Deutschland. In Boden gut gemacht. Die Sanierung des Rüstungsaltstandortes Stadtallendorf, ed. Hessisches Ministerium für Umwelt. Wiesbaden: Hessisches Ministerium für Umwelt, 21-63.

Reichsschatzministerium, Listen der Orte, an denen Zerlegungsarbeiten von Munition vorgenommen wurden oder wo dies beabsichtigt ist, 1. Zerlegestellen für Eisenmunition und Metallkartuschen (1919-1922), BArch 2201/3225.

Reile, Heidrun. 2005. Kosten. In Boden gut gemacht. Sie Sanierung des Rüstungsstandortes Stadtallendorf, ed. Hessisches Ministerium für Umwelt. Meckenheim, 419-424.

Report on the C.W. Experimental Station at Raubkammer bei Munster and related Establishments. C.D.R-5. Enemy C.W. and Smoke Intelligence Summary, No. 83, 1945, The National Archives, WO 208/3576.

Rundschreiben der Monturon GmbH, Nr. 914/45/IVa1/Pr. an die Montan-Industriewerke GmbH betreffend Betriebsstillegungen und Verlagerungen. February 1945. Private Collection Preuss.

Schaefer, Karl Wolfram, Frank Boeren, Sergei Boutsev, et al. 1997. Internationale Erfahrungen der Herangehensweise an die Erfassung, Erkundung, Bewertung und Sanierung Militärischer Altlasten. UBA Text 4 (97): 139-144.

Schmaltz, Florian. 2005. Kampfstoff-Forschung im Nationalsozialismus. Zur Kooperation von Kaiser-Wilhelm-Instituten, Militär und Industrie. Göttingen: Wallstein.

Scholz, Ernst-Gerhardt. 2004. Stoltzenberg-Skandal. Zuerst starb ein Kind. Hamburger Abendblatt, September 7.

Schreiben der Luranil-Baugesellschaft mbH (in Auflösung) an das IG Farben Control Office (Liquidation section), Frankfurt am Main betreffend Silbermaterial. January 18, 1951. Private Collection Preuss.

Schreiben der Waffenamt-Forschungsabteilung (WaF) an den Chef Wa J Rü betreffend Muna-Ost. December 1938. Private Collection Preuss.

Schreiben der Waffenamt-Forschungsabteilung (WaF), Nr. 595/39 gKdos Wa F/A2, an Wa J Rü 10 und Wa J Rü (Mun3) betreffend MO, Büro Prof. Loos. January 30, 1940. Private Collection Preuss.

Schreiben des Oberkommandos des Heeres (Ch H Rüst u BdE), 70 o 3018 Wa J Rü (Mun 3 zbV/VIII), Nr. 10006/43 g.Kdos., an I.D. Riedel - E. de Haen AG, Berlin-Britz betreffend Sonderbauvorhaben OKH. February 18, 1943. Private Collection Preuss.

Schreiben des Oberkommandos des Heeres (Ch H Rüst u BdE), Wa J Rü Stab IV d an das Oberkommando der Wehrmacht $(\mathrm{OKW})$, W Stab W Rü, betreffend M.-O., Falkenhagen, Erwerb von Flussspatgruben, Antrag auf Bestimmung einer Bedarfsstelle. January 1940. Private Collection Preuss. 
Schreiben von Oberst a.D. Hammer, Falkenhagen an die Verwertungsgesellschaft für Montanindustrie $\mathrm{GmbH}$, München. September 18, 1943. Private Collection Preuss.

Schweer, Henning. 2008. Die Geschichte der Chemischen Fabrik Stoltzenberg bis zum Ende des Zweiten Weltkrieges. Ein Überblick über die Zeit von 1923 bis 1945 unter Einbeziehung des historischen Umfeldes mit einem Ausblick auf die Entwicklung nach 1945. Diepholz: GNT Verlag.

Sekretariat K, Bericht, Betrifft: Orgacid GmbH Der Betrieb liegt still und hat eine amerikanische Wache von etwa 30 Mann. Die Orgacis beschäftigt 42 Arbeiter..., Essen, May 28, 1945. Private Collection Preuss.

Sonderausschuss $\mathrm{C}$ beim Reichsminister für Rüstung und Kriegsproduktion, Bericht über die Lage auf dem Kampfstoffsektor, Auszug aus dem Vortrag im Führerhauptquartier am 15.03,1943 mit einer Gegenüberstellung der Situation vom 01.03,1944, March 3, 1944. BArch Berlin, R $3 / 1894$.

Sonderausschuss C, Arbeitsbüro: Fertigungsbericht C-Stoffe für Dezember 1944. BArch Berlin, R 3/1894.

Spezialstab ATV, Gruppe Ausbildungsmaterial, Kampftruppenschule 2, 90 Jahre Truppenübungsplatz Munster 1883-1993, 6-21, Munster 1983.

Stoltzenberg, Dietrich. 1994. Fritz Haber-Chemiker, Nobelpreisträger, Deutscher, Jude. Weinheim: VHC Wiley.

Szöcs, Andreas. 1999. Geoökologische Systemanalyse und Bestimmung der Nitroaromatenmobilität auf dem großflächigen Rüstungsaltstandort Stadtallendorf bei Marburg. PhD dissertation, University of Mainz, Göttingen: Cuvillier Verlag.

Thieme, Jürgen. 1996. Bestandsaufnahme von Rüstungsaltlastverdachtsstandorten in der Bundesrepublik Deutschland. UBA Text 25/96-30/96.

Thieme, Jürgen. 1999. Umweltrelevante und technische Aspekte der Zerlegung von Munition und Waffen nach dem 1. Weltkrieg. UBA Text 3: 99.

Transcription of the copy from Handelsregister, Amtsgericht Halle an der Saale, Department B, December 23, 1937. Private Collection Preuss.

Verfügung der Landesregierung Brandenburg, Enteignungsurkunde für das beschlagnahmte Betriebsvermögen der Firma M.O. Falkenberg (!), Falkenberg, Kreis Lebus. July 7, 1848. Private Collection Preuss.

Vertrag zwischen dem Deutschen Reich (Wehrmachtsfiskus), vertreten durch das Oberkommando des Heeres $(\mathrm{OKH})$, der Verwertungsgesellschaft für Montanindustrie $\mathrm{GmbH}$, der IG Farbenindustrie AG und der Monturon $\mathrm{GmbH}$ über die Erweiterung der $\mathrm{OKH}$-eigenen N-Stoff-Anlage durch eine Fabrikationsstätte zur Herstellung von 500 metric tons monthly Sarin. June 3, 1944. Private Collection Preuss.

Vertrag zwischen der Chemischen Fabrik Buckau (Ammendorf), der Degea-Aktiengesellschaft (Auergesellschaft), Berlin, und dem Deutschen Reich (Fiskus des Wehrmachtsteils Heer), vertreten durch den Reichskriegsminister (Rkm) über die Errichtung einer Polyglykolfabrik und einer Umsetzungsanlage. September 20, 1935. Private Collection Preuss.

Wehrmacht-Fernsprechverzeichnis Groß-Berlin Teil I, p. 147. February 1, 1943. National Archives, Washington DC., Microfilm T-77, reel 342.

Wehrmachts-Fernsprechverzeichnis Groß-Berlin, Ministerial Dirigent Dr. Zahn Abteilungs- Chef z. b. V, Abteilung Chef-Chemiker (Wa A). June 6, 1943, part I, p. 144. National Archives, Washington, DC., Microfilm T-77, reel 342.

Williams, C., Burning of Mustard Gas and Lewisite at No. 81 M.U., R.A.F., Bowes Moor, Estimation of Risk. Summary of Porton Report No. 2744. January 1, 1947. National Archives, Washington, DC., RG 338.

Zimmermann, K., and H. Martens. 1994. Kontamination von militärischen Gelände im Raum Munster durch Arsenverbindung. Abfallwirtschaftsjournal 6 (6/7): 510-513. 
Open Access This chapter is licensed under the terms of the Creative Commons Attribution-NonCommercial 2.5 International License (http://creativecommons.org/licenses/by-nc/ $2.5 /$ ), which permits any noncommercial use, sharing, adaptation, distribution and reproduction in any medium or format, as long as you give appropriate credit to the original author(s) and the source, provide a link to the Creative Commons license and indicate if changes were made.

The images or other third party material in this chapter are included in the chapter's Creative Commons license, unless indicated otherwise in a credit line to the material. If material is not included in the chapter's Creative Commons license and your intended use is not permitted by statutory regulation or exceeds the permitted use, you will need to obtain permission directly from the copyright holder.

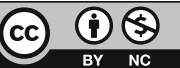

